\title{
Yarı Kurak Ekolojik Koşullar Altında Tarımsal Arazi Kullanım Planlamasının Hazırlanması: Ankara-Kalecik Örneği
}

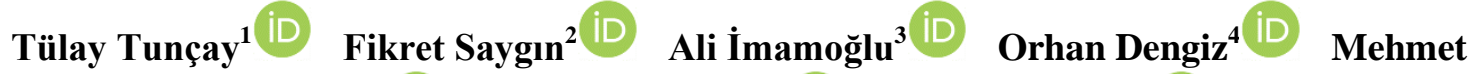 \\ Keçeci $^{1}$ iD Mustafa Usul $^{5}$ iD Oğuz Başkan*6 iD \\ ${ }^{1}$ Toprak Gübre ve Su Kaynakları Merkez Araştırma Enstitüsü, Yenimahalle, Ankara. \\ ${ }^{2}$ Karadeniz Tarımsal Araştırma Enstitüsü, Samsun. \\ ${ }^{3}$ Nevşşehir Hacı Bektaş Veli Üniversitesi, Coğrafya Bölümü, Nevşehir. \\ ${ }^{4}$ Ondokuz Mayıs Üniversitesi Ziraat Fakültesi Toprak ve Bitki Besleme Bölümü, Atakum, Samsun. \\ ${ }^{5}$ Tarım Reformu Genel Müdürlüğü Toprak Koruma Arazi Değerlendirme Daire Başkanlığı, Ankara. \\ ${ }^{6}$ Siirt Üniversitesi Ziraat Fakültesi Toprak ve Bitki Besleme Bölümü, Kezer Yerleşkesi, Siirt. \\ *Sorumlu yazar: ogbaskan@yahoo.com
}

Geliş Tarihi: 08.07.2021

Kabul Tarihi: 27.10.2021

\section{$\ddot{O} z$}

Giderek artan dünya nüfusu, başta topraklar olmak üzere yenilenemez olan doğal kaynakların daha verimli kullanılma zorunluluğunu beraberinde getirmiştir. Arazi kullanım kararları başlangıçta arazi sahiplerinin kısa vadeli gereksinimleri doğrultusunda alınırken, günümüzde arazi kullanımın kararlarının doğal kaynaklara kalıcı zararlar vermeyecek şekilde alınabilmesi için arazi kullanım planlarının yapılması ve uygulamaya konulmasını gerektirmektedir. Her türlü arazi kullanım planlamasında birincil amaç, tarım topraklarının gelecek nesiller için korunarak sürdürülebilir kullanımı sağlamaktır. $\mathrm{Bu}$ nedenle, özellikle tarımsal arazi kullanım planlamaları toprakların özellik, dağılım ve potansiyellerinin belirlendiği temel toprak etüd ve haritalama çalışmalarına dayanarak yapılmaktadır. Planlama kararlarının sağlıklı olarak alınabilmesi amacıyla, yeterli doğrulukta ve ayrıntılı bilgileri içeren toprak etüd ve haritalama çalışmalarına ihtiyaç bulunmaktadır. Detaylı toprak haritaları esas alınarak yapılan arazi değerlendirme çalışmaları sonucu arazilerin son kullanıcılara alternatif kullanımlara uygunluğunun belirlenmesi esasına dayanır. Daha sonra planlama amaçlarıyla örtüşen arazi kullanımları seçilmiştir. Bu araştırma dijital alt yapılı güncellenebilir Türkiye topraklarının toprak etüt ve haritaların oluşturulmasına alt yapı oluşturması amacıyla Ankara ili Kalecik ilçesinde yürütülmüştür. Uydu görüntüleri, sayısal yükseklik modelleri, topoğrafik haritalar ve jeoloji haritaları kullanılarak toprak profil noktaları belirlenmiştir. Açılan profiller tanımlanarak taslak toprak haritası oluşturulmuş, daha sonra arazi gözlemleri ve örneklemeler ile seri sınırları kesinleştirilmiştir. İkinci aşamada arazi kullanım türleri, bu türlerin toprak istekleri belirlenerek toprak serileri özellikleri ile eşleştirme yapılmış ve toprak özelliklerine göre tarımsal arazi kullanım planlaması oluşturulmuştur.

Anahtar Kelimeler: Tarımsal arazi kullanım planlaması, Arazi uygunluğu, Kalecik

\section{Generating of Agricultural Land Use Planning under Semi-Arid Ecological Condition. Case Study, Ankara-Kalecik \\ Abstract}

It is the necessity to use of natural resources productively, mainly soils that are not renewable due to increasing world population. In the beginning, land use programs are taken short demands of landowners, it is necessity to land use plan and put into practice for not cause permanent damage to natural resources. The first aim of all kinds of land use planning, agricultural soils are protected for sustainable use for future generations. For this purpose land use plans are performed based on soil survey and mapping studies that determine soil distribution and properties. Soil survey and mapping studies that have sufficient precision and include detail knowledge are needed for purpose taking robust plan decisions. Land evaluation studies based on detailed soil maps are the basis for determining the suitability of the end-use land for alternative uses. Afterwards land uses that overlap with the planning purposes are selected. The research was conducted in Ankara Kalecik district in order to create infrastructure of being updatable digital soil map of Turkey. Soil profile points were determined using satellite imagery, digital elevation models, topographic maps and geological maps. A draft soil map was created by defining the profiles, and then the field observations and samples and sequence boundaries were 
finalized. In the second stage, land use patterns were determined, and soil types were identified and paired with soil series characteristics and new land use planning was established according to soil characteristics.

Keywords: Agricultural land use planning, Land suitability classification, Kalecik

\section{Giriş}

Dünya nüfusunun hızlı bir şekilde artmaya devam etmesi doğal kaynaklar üzerindeki baskının artması sonucunu ortaya çıkarmaktadır. Bu nedenle, tarımsal üretim için gerekli olan en önemli doğal varlıklardan olan topraklar üzerinde sürdürülebilir tarımsal faaliyetlerin planlanması ve uygulanması önem arz etmektedir. Ülkemizde artan arazi kullanım talepleri sonucunda, verimli tarım arazilerinin amaç dışı, plansız ve kontrolsüz kullanımı çeşitli çevre sorunlarını da beraberinde taşımaktadır. $\mathrm{Bu}$ nedenle, arazi kullanımına yönelik alınacak kararların bilimsel arazi değerlendirme çalışmaları sonuçlarına göre uygulanmasının önemi büyüktür (Dengiz ve ark., 2003; Turan ve ark., 2010; Abdelrahman ve ark., 2016). Bu kapsamda, detaylı toprak etüt çalışmaları ile toprakların uygun şekilde sınıflandırılarak temel karakteristiklerinin belirlenmesi ve toprak haritalarının üretilmesi gerekmektedir. Elde edilen temel veri tabanına göre, iklim ve arazi karakteristikleri de dahil edilerek arazi kullanım türlerinin belirlenebileceği arazi kullanım planları ve haritalarının oluşturulması ön plana çıkmaktadır (FAO, 1976; Smyth ve Dumanski, 1993). Arazi kullanım haritalarının oluşturulmasında sadece yörenin toprak özelliklerinin değerlendirilmesi yerine, yörenin ekonomik çıktı, sürdürülebilirlik ve sosyo-kültürel değerlerinin de dikkate alınması önem taşımaktadır. Seçilen üretim deseni en yüksek verim alınabilecek olması ekonomik, sürdürülebilir olması anlamına gelmemektedir. Bu nedenle FAO arazi kullanım planlaması yapılırken sosyal, ekonomik ve çevresel etmenlerinde ele alınmasını kapsayan bir rehber geliştirmiştir (FAO, 1989; Cinemre ve Dengiz, 2010). Demirel ve Şenol (2019) hızlı büyüme potansiyeline sahip yerleşim alanlarındaki detaylı toprak etütleri ve arazi değerlendirmelerinin önemine vurgu yapmışlar ve nüfus artışının kentsel alan ihtiyacını artırması yoluyla tarım alanlarını tehdit ettiğini vurgulamışlardır. Adana İli Mustafalar köyünde detaylı toprak etüt- haritalama çalışması yürüterek ideal ve potansiyel arazi kullanım planları oluşturmuşlardır.

Kınalı ve ark. (2020), Isparta İslamköy ve yakın çevresinde yaptıkları çalışmada arazi toplulaştırma çalışmalarını ekolojik temele dayanan planlama yaklaşımı ile optimal alan kullanımlarını mekânsal olarak değerlendirmişlerdir. Çalışmada araştırma alanının doğal yapısı, mevcut alan kullanımları ve sosyo-ekonomik yapısı ortaya çıkarılmış, tarım, orman, çayır-mera, rekreasyon, yerleşim ve sanayi kullanım türleri için uygun alan kullanımları CBS ve çok kriterli analiz metodu kullanılarak belirlenmiştir. Dengiz ve ark. (2009), Doğu Karadeniz Bölgesinde findık arazilerinin tarımsal kullanıma uygunluk sınıflarının belirlenmesine yönelik yaptıkları çalışmada, arazi kullanım türleri ve onların arazi isteklerini belirlemişlerdir. Arazi kullanım türlerinin arazi istekleri ile arazi haritalama birimlerinin arazi karakteristik ve nitelikleri karşılaştırılarak, her bir arazi haritalama birimi için uygun olan arazi kullanım türleri ve uygunluk sınıflarını belirlemişlerdir. Araştırma alanının arazi uygunluk haritası sonucunda, alanın \% 28,4'ünün tarım dışı araziler oluştururken, \% 34,6'sını tarımsal kullanım için uygun ve oldukça iyi tarım arazileri oluşturmaktadır. Ayrıca, Aydın ve Dengiz (2020), Samsun İli Kavak İlçesi sınırları içerisinde yer alan altı köyü kapsayan 397 ha'lık alanda ILSEN arazi değerlendirme programı ile potansiyel arazi kullanım gruplarının ve tarımsal arazi kullanımı uygunluk sınıflarının belirleme çalışmasını yürütmüşlerdir. Çalışmada alanın yaklaşık \%51'i sorunlu tarım arazileri oluştururken, alanın sadece \% 1,2'si tarım dışı araziler olarak belirlenmiştir.

$\mathrm{Bu}$ çalışma ile Ankara Kalecik İlçesinin detaylı toprak haritasından yararlanılarak, yöre arazilerinin mümkün olan en iyi şekilde kullanımının ve sürdürülebilir yönetiminin sağlanması amacıyla ilçenin ekolojik özelliklerine adapte olmuş ve/veya olabilecek arazi kullanım türlerinin belirlenmesi ve bu arazi kullanım türlerinin toprak istekleri göz önüne alınarak arazi değerlendirmesinin yapılması hedeflenmiştir. Bu hedef doğrultusunda, ILSEN arazi değerlendirme programı ve haritaların oluşturulması için Coğrafi Bilgi Sistemi (CBS) etkin bir şekilde kullanılmıştır.

Materyal ve Yöntem

Materyal

Araştırma alanı özellikleri 
Ankara-Kalecik ilçesini kapsayan yaklaşık 116.009 ha yüzölçümlü çalışma alanı, 521000549000 D ile 4430000-4470000 K (UTM, WGS-84 m) koordinatları içerisinde yer almaktadır. Ankara'nın kuzey doğusunda yer alan çalışma alanı deniz seviyesinden $580 \mathrm{~m}$ ile $1984 \mathrm{~m}$ arasındaki yükseklikte yer almaktadır (Şekil 1).

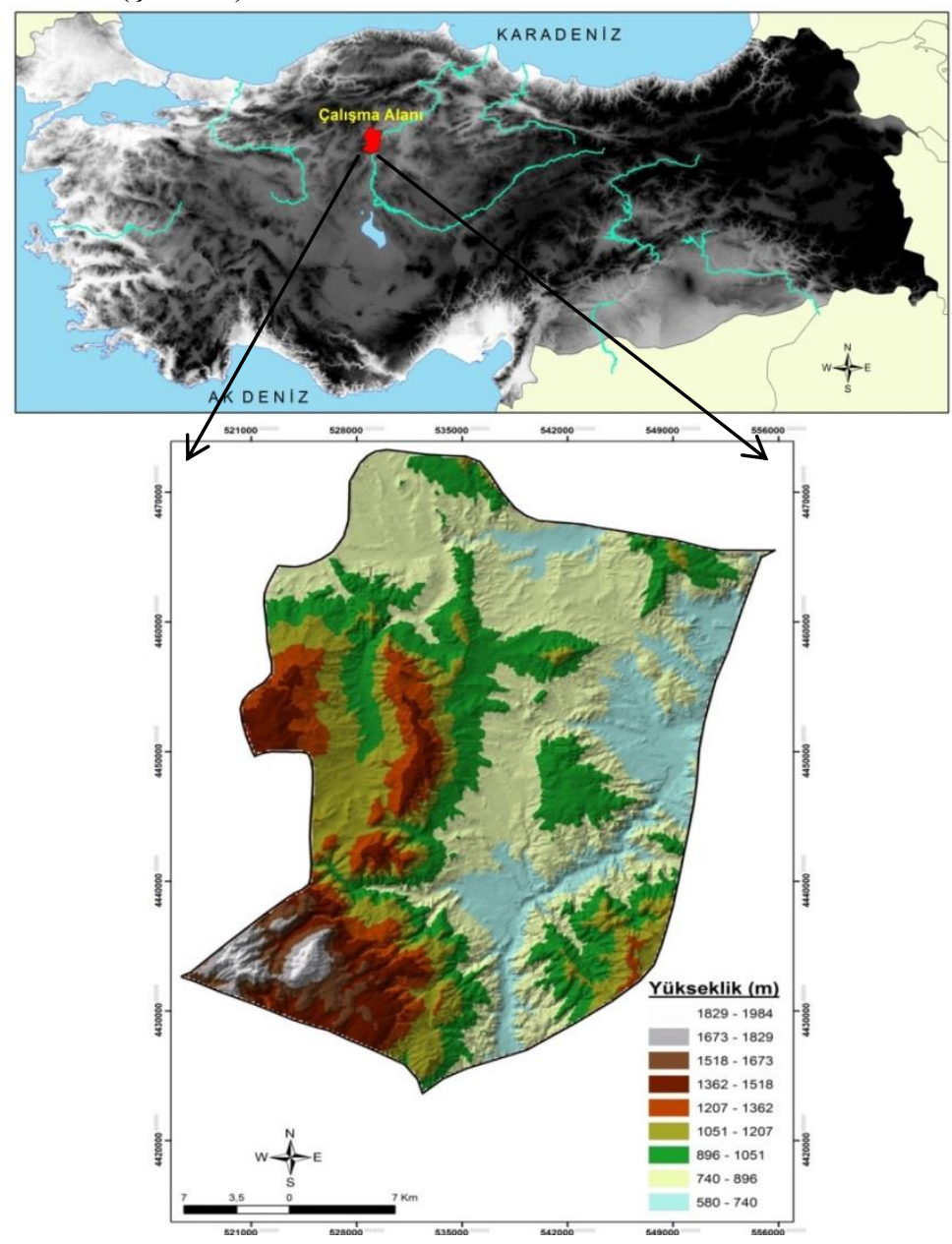

Şekil 1. Çalışma alanı yer bulduru ve yükselti haritaları

Çalışma alanına en yakın olan uzun yıllara ait (1960-2015) Kırıkkale meteoroloji istasyonu verileri kullanılarak toprakların Thornthwaite yöntemine göre su bilançosu tablosu oluşturulmuş ve iklim diyagramı çizilmiştir (Şekil 2). Buharlaşma eğrisi mart ortalarından ekim ortalarına kadar yağış eğrisinin üzerinde seyretmektedir. Mart sonu, nisan ve mayıs aylarında toprakta birikmiş su kullanıldığından bu aylarda kuraklık etkili değildir. Buna karşılık haziranda etkili olmaya başlayan kuraklık ekim ortalarına kadar devam etmektedir. Thorthwaite metoduna göre Kırıkkale D harfi ile gösterilen yarı kurak iklim tipine dâhil olmaktadır. Ayrıca $\mathbf{b}{ }_{2} \mathbf{d} \mathbf{b}{ }^{2}$ harfleri ile ifade edilen orta sıcaklıkta, su fazlası olmayan ya da çok az olan, kara tesirine yakın iklim tipi olarak sınıflandırılabilir. 


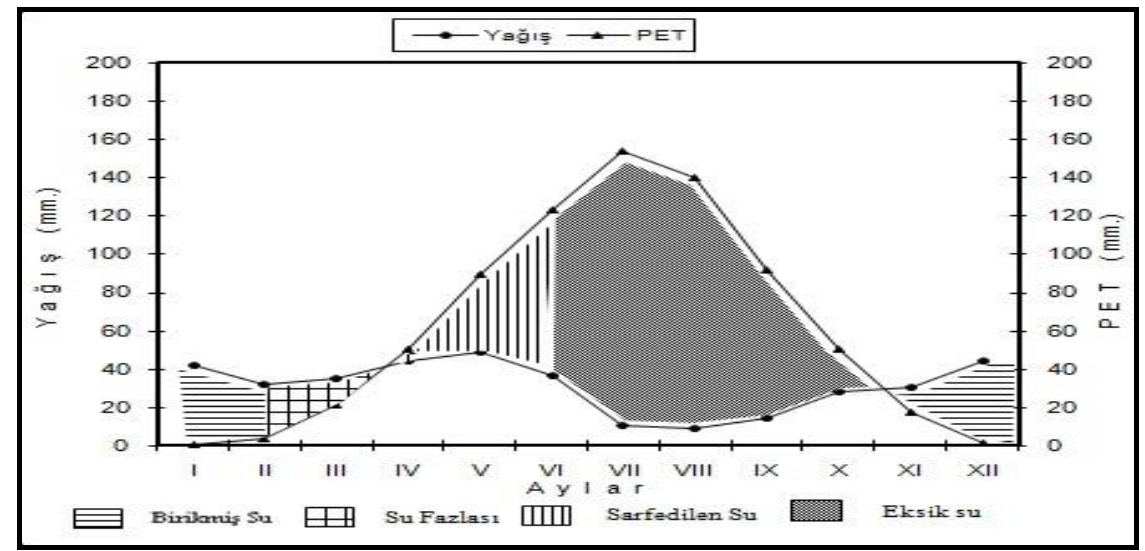

Şekil 2. Kırıkkale'nin su bilançosu diyagramı (1960-2015).

Avrupa Çevre Ajansı tarafindan belirlenen, arazi örtüsü/arazi kullanım, Coordination of Information on the Environment (CORINE 2018) sınıflamasına göre çalışma alanının arazi kullanım ve arazi örtüsü dağılım durumu Çizelge 1 ve Şekil 3 de verilmiştir. Çalışma alanında en az dağılım alanı ile karasal sular, karasal bataklık, maden ocakları ve orman alanları oluştururken en geniş dağılım ise toplam alanın \%35,2’lik kısmı ile ekilebilir alanlar dağılım göstermektedir.

Çizelge 1. CORINE arazi örtüsü ve arazi kullanım sınıflamasına göre alansal ve oransal dağılımı

\begin{tabular}{lrr}
\hline Arazi Kullanım ve Arazi örtü Sınıfları & ha & $\%$ \\
\hline Bitki örtüsü az ya da olmayan alanlar & 35405,45 & 30,5 \\
Ekilebilir alanlar & 40815,50 & 35,2 \\
Karasal bataklıklar & 50,45 & 0,1 \\
Karasal sular & 35,87 & 0,0 \\
Maden ocağı boşaltım ve inşaat sahalar & 42,18 & 0,0 \\
Orman & 408,43 & 0,4 \\
Karasal sular & 35,60 & 0,0 \\
Karışık tarımsal alanlar & 23745,35 & 20,5 \\
Maki veya otsu bitkiler & 13469,64 & 11,6 \\
Meralar & 1350,40 & 1,2 \\
Yerleşim & 702,3 & 0,6 \\
\hline Toplam & 116025,3 \\
\hline
\end{tabular}

Araştırma alanının 1:25.000 ölçekli sayısal jeoloji haritası Şekil 3'de ve jeolojik materyallerin alan içerisindeki dağılım alanları Çizelge 2 de sunulmuştur. Alan içerisinde $\% 41,9$ ile en fazla çakıl taş1+ kum taşı ve çamur taşından oluşan yapının olduğu görülmektedir. Çalışmanın kuzey doğusunda evoporitler yer alırken güneyinde ise en yaygın olarak volkanitlerin yer aldığı görülmektedir. 
ÇOMÜ Zir. Fak. Derg. (COMU J. Agric. Fac.)

2021: 9 (2): 339-358

ISSN: $2147-8384$ / e-ISSN: 2564-6826

doi: $10.33202 /$ comuagri.964808

Çizelge 2. Araştırma alanına ait jeolojik materyallerin alansal ve oransal dağılımları

\begin{tabular}{|c|c|c|}
\hline Jeolojik Materyal & ha & $\%$ \\
\hline Aluvyal Depositler & 8185,58 & 7,1 \\
\hline Çak1ltaş1 + kumtaş1 + çamurtaş1 & 48580,58 & 41,9 \\
\hline Melanj & 13728,32 & 11,8 \\
\hline Kireç Taşı & 6813,96 & 5,6 \\
\hline Evaporitler & 2305,48 & 2,0 \\
\hline Spilit (Kolüvyal) & 817,13 & 0,7 \\
\hline Andezit+Bazalt+Dasit & 1804,86 & 1,6 \\
\hline Çörtlü Kireçtaş1 & 501,31 & 0,5 \\
\hline Olistostrom (Kolüvyal) & 2868,23 & 2,5 \\
\hline Metaolisostrom & 11652,79 & 10,2 \\
\hline Metavolkanitler & 37,32 & 0,0 \\
\hline Volkanit + çökel kaya & 17422,32 & 15,0 \\
\hline Levha Dayk & 979,58 & 0,8 \\
\hline Çört+ Bazalt+ Seyl & 59,52 & 0,0 \\
\hline Göl & 28,70 & 0,2 \\
\hline Monazit & 148,76 & 0,1 \\
\hline Şist & 49,36 & 0,0 \\
\hline Toplam & 116025,3 & 100,0 \\
\hline
\end{tabular}

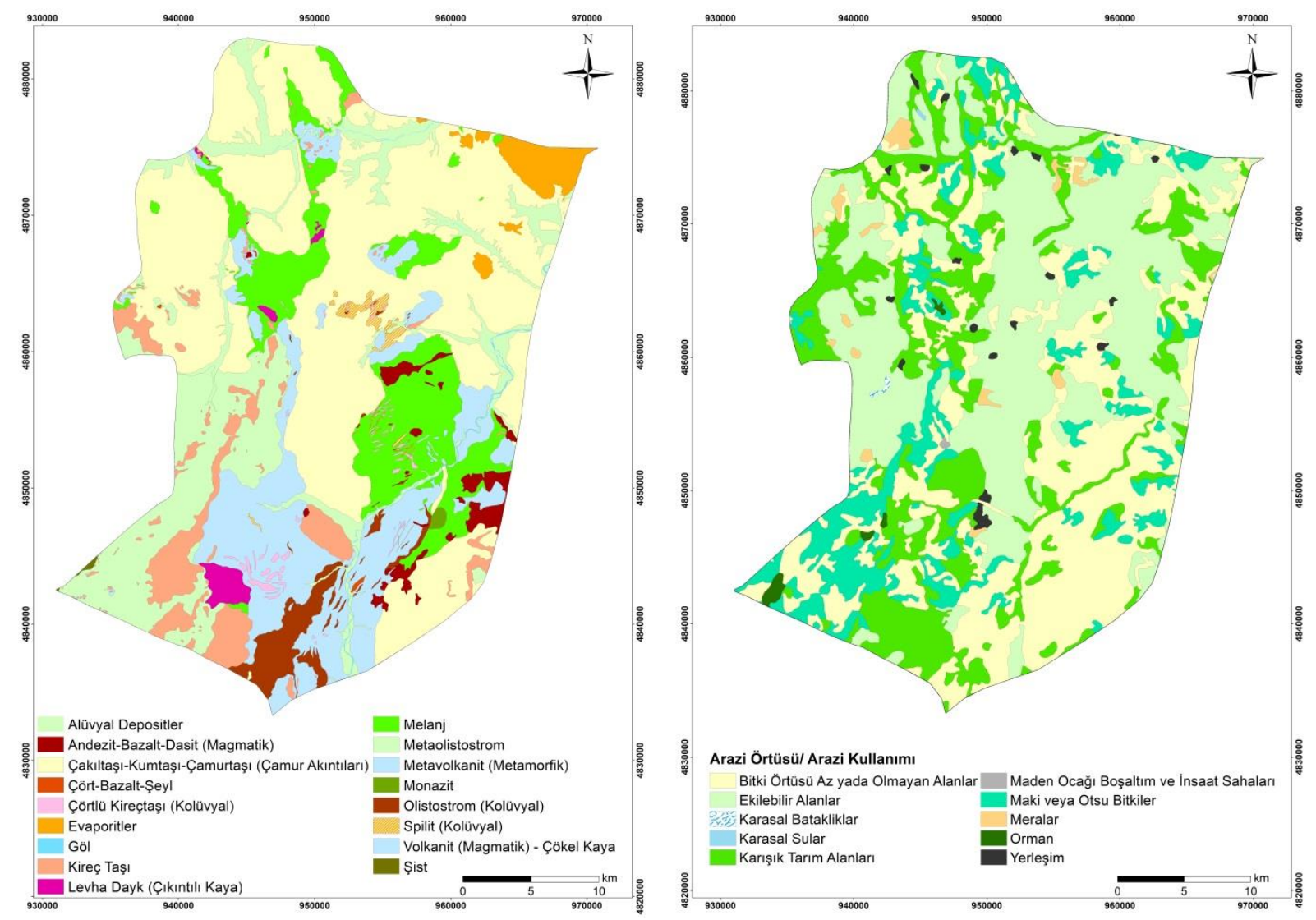

Şekil 3. Çalışma alanı jeoloji ve arazi örtüsü ve arazi kullanım haritası 


\section{Yöntem}

$\mathrm{Bu}$ araştırma toprak veri tabanının oluşturulması ve arazi değerlendirme çalışması olmak üzere iki aşamada yürütülmüştür.

İlk aşamada yaklaşık olarak 116.009 ha olan çalışma alanı mevcut bitki deseni ve arazi kullanımı ile topografik haritalardan üretilen Sayısal Arazi Modeli (SAM) kullanılarak alanda yayılım gösteren farklı fizyografik üniteler, eğim, rölyef, bakı ve arazi şekilleri oluşturulmuştur. Arazi şekli ve arazi örtüsü, jeolojik verileri ile birleştirilerek farklı ana materyal ve farklı fizyografya üzerinde oluşmuş toprakların belirlenmesine yönelik 56 adet profil açılmıştır. Açılan bu profillerin arazi ve laboratuvar çalışmaları sonucu elde edilen verilere göre toprak sınıflama sisteminin en alt kategorik seviyesi olan Seri seviyesinde 16 adet tanımlanmış, 1518 adet haritalama birimi ise bu serilere ait üst toprak tekstürü, eğim, derinlik, drenaj, erozyon, taşl1lık ve kayalıl1ktan oluşan faz grupları oluşturularak alana ait temel toprak haritası ve veri tabanı oluşturulmuştur. Ayrıca alanın toprak sınıflama sistemi içerisinde büyük grup düzeyde alansal dağılım ve oranları Çizelge 3 ve Şekil 4 de verilmiştir. Buna göre çalışma alanında \%35, 9 ile en fazla dağılıma sahip büyük toprak grubu Lithic Xerorthent iken, en az alan 72,2 ha ile Aquic Xerofluvent olarak belirlenmiştir.

Çizelge 3. Toprak sınıflarının alansal ve oransal dağılımları

\begin{tabular}{lrr}
\hline Toprak Taksonomisi (1999) & Alan (ha) & Oran(\%) \\
\hline Typic Xerofluvent & 4451,9 & 3,8 \\
Vertic Xerofluvent & 5887,3 & 5,1 \\
Aquic Xerofluvent & 72,5 & 0,1 \\
Typic Xerorthent & 22405,1 & 19,3 \\
Lithic Xerorthent & 41606,5 & 35,9 \\
ENTISOL & $\mathbf{7 4 4 2 3 , 3}$ & $\mathbf{6 4 , 2}$ \\
Vertic Haploxerept & 4367,4 & 3,8 \\
Lithic Haploxerept & 3444,7 & 3,0 \\
Typic Haploxerept & 10816,1 & 9,3 \\
Typic Calcixerept & 7997 & 6,9 \\
Vertic Calcixerept & 4310,9 & 3,7 \\
INCEPTISOL & $\mathbf{3 0 9 3 6 , 1}$ & $\mathbf{2 6 , 7}$ \\
Typic Haploxeret & 10519,3 & 9,0 \\
VERTISOL & $\mathbf{1 0 5 1 9 , 3}$ & $\mathbf{9 , 0}$ \\
Çוplak Kayalı & 146,4 & 0,1 \\
\hline Toplam & 116025,3 & 100 \\
\hline
\end{tabular}

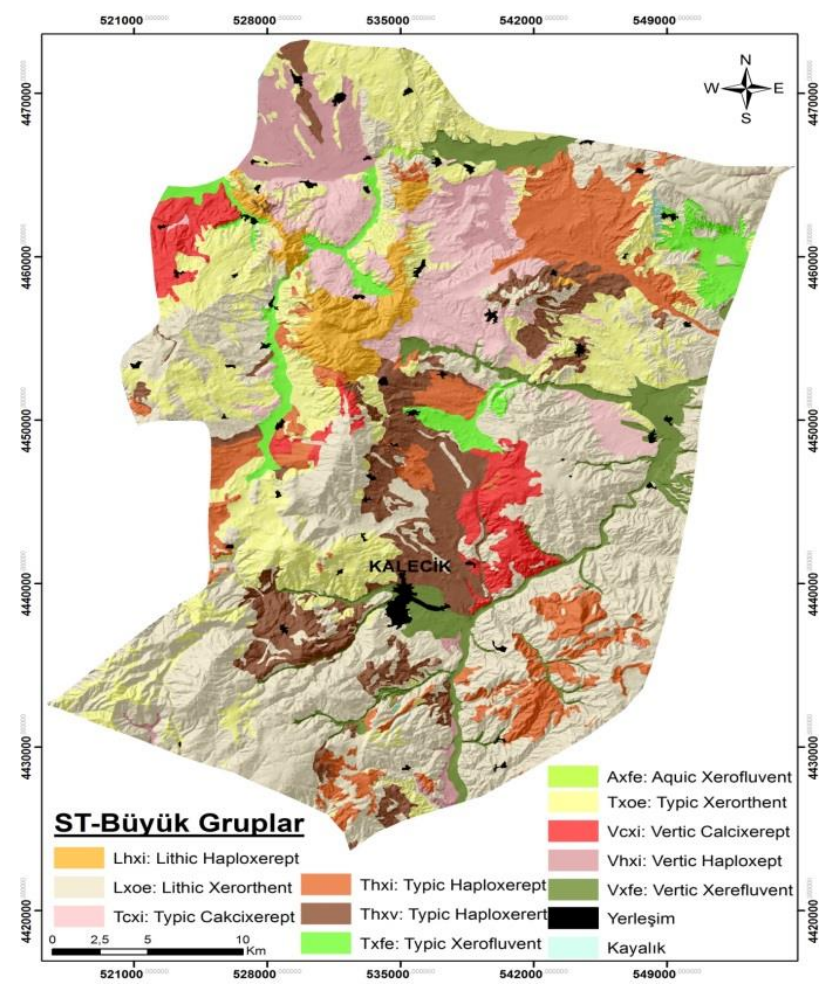


Çalışmanın ikinci aşamasını ise yöre için yapılacak arazi kullanım planlaması oluşturmaktadır. Arazi kullanım planlamasına temel teşkil etmek üzere, yerel tarım teşkilatı ve çiftçilerle görüşülerek önerilecek arazi kullanım türlerinin belirlenmesi için gerekli veriler toplanmıştır. Belirlenen arazi kullanım türlerinin arazi istekleri tespit edildikten sonra, çalışma alanına ait serilerin toprak özellikleri ile İLSEN arazi değerlendirme programı kullanılarak eşleştirilmiştir. Ayrıca sorgulamaları sonrasında hazırlanan arazi kullanım planlarına eşlik eden alternatif ürünlere ait muhtelif haritalar ile birçok toprak ve topoğrafik özelliğe ait tematik haritalar oluşturulmuştur. FAO (1977)'de belirtilen ilkeler 1şığında Şenol ve Tekeş (1995) tarafından geliştirilmiş olan yöntem, arazi değerlendirmesi ve uygun arazi kullanım seçeneklerinin belirlenmesine olanak sağlayan parametrik bir yaklaşımdır. Aynı zamanda CBS ile uyumlu olarak çalışabilen yöntem ILSEN paket program olarak kişisel bilgisayarlarda kolaylıkla kullanılabilmektedir.

Yöntemin diğer arazi değerlendirme metotlarından en önemli avantajları karlılık, iklim ve sosyal etkenleri de içerisinde barındırması ve araziyi her yönüyle değerlendirebiliyor olmasıdır. $\mathrm{Bu}$ sayede çalışılan bölge toprakları için en karlı ürün seçimi yapılabilmektedir. Aynı zamanda çeşitli üniversitelerden bilim insanlarının ve farklı agronomistlerin katkıları ile ülkemizde yetiştirilebilen farklı 150 bitki türü için 101 adet toprak karakteristiği ve iklim istekleri program içerisinde modellenmiş olup, gerekli durumlarda bu faktörlerin her biri için ayrı ayrı modifikasyon yapilabilmektedir.

ILSEN istenilen arazi kullanım türlerine göre toprakları skorlayan parametrik bir yaklaşımdır. Bu sebeple istenilen arazi kullanım türlerine göre toprak ve arazi karakteristiğinin değişik düzeylerinin üretime olan oransal katkıları ekolojik kriterler de göz önünde bulundurularak değişiklik göstermektedir. Programda, 150 arazi kullanım türlerinin (AKT) her birisinin toprak ve arazi isteklerini dikkate alarak programlanmış olup, AKT'ler için belirlenen farklı düzeylerdeki toprak karakteristik skorlarına Oransal Beklenen Ürün Değerleri (OBÜ) denilmektedir. OBÜ değerleri skorlanırken, herhangi bir toprak veya arazi karakteristiği AKT'lerinden herhangi birisinin isteklerini tam olarak karş1liyor ise 1.00, hiç karşılamıyor ise 0.00 değerini alacak şeklinde değerlendirilmektedir. AKT isteklerinin değişen düzeylerde karşılanması halinde de OBÜ değeri 0.00 ile 1.00 arasında skorlanmaktadır. Toprak skorlarının elde edilmesinde toprak derinliği, üst toprak tekstürü, alt toprak tekstürü, geçirgenlik, tuzluluk, drenaj, yüzey taşlılığı, yüzey kayalılığı, eğim, su ve rüzgar erozyonu, toprak ana materyali, profil boyu taşl1lık ve çakıllılık durumu, alt toprağın katyon değişim kapasitesi, kireç içeriği, vertik özellik, strüktür, alkalilik, bor içeriği, toprak $\mathrm{pH}$ ve organik madde içeriği gibi toprak karakteristikleri kullanılmaktadır.

Toprak karakteristiklerinin FAO (1977)'de belirtilen ilkeler 1şığında ilişkilendirilmesi ile Tarımsal Kullanıma Uygunluk Sınıfları (TKUS) elde edilmektedir. TKUS değerleri, her bir haritalama birimini sahip oldukları tarımsal üretim potansiyeline göre skorlamaktadır. TKUS skorları aşağıdaki formülasyon ile hesaplanmaktadır. TKUS skorları ve sınıfları Çizelge 4' de verilmiştir.

TKUS $=($ A $\times$ B $\times$ C x ...n $) / 100^{\text {n }}$

Burada,

A, B, C... = Toprak karakteristik değerleri

Toprak karakteristiklerinin farklı arazi kullanım türlerine ne kadar uygun olduğunu gösteren OBÜ değerleri ve toprakların üretim potansiyelini skorlayan TKUS değerleri en uygun arazi kullanım türünün belirlenmesinde tek kıstas değildir. Nitekim ekolojik isteklerin ve karlılık değerlerinin de arazi kullanım türünün seçilmesinde uygunluğu bilinmelidir. Yetiştirilmek istenilen bitki türü için ekolojik istekler uygun ise 1 uygun değil ise 0 değerleri yazılıma girilmektedir. Metot içerisinde halihazırda 150 arazi kullanım türü için literatür destekli olarak ekolojik istek tablosu ve veri tabanı oluşturulmuş durumdadır. Benzer şekilde AKT'ler için farklı ekolojilerde karlılık değerleri metot içerisinde tanımlanmış ve Karlılık Endeks (KE) değerleri olarak adlandırılmıştır. Karlılık endeksleri, farklı arazi kullanım türlerinin farklı ekolojilerde üreticiye sağladığı ekonomik faydadır. Örneğin Konya ilinde buğday bitkisi için karlılık endeksi 1.00 olarak değerlendirilirken aynı bölgede muz bitkisi için 0.00 karlılık endeksi tanımlanmaktadır. Bu bağlamda farklı ekolojik şartlarda farklı arazi kullanım türleri 0 ile 1 arasında değişen değerlerde tanımlanmıştır. Yine de ekolojik istekler ve karlılık endeksi için veri tabanı kullanıcının yorumuna bırakılmış ve spesifik yetiştiricilikler için değiştirilebilir olarak 
hazırlanmıştır. Program içerisinde tanımlanmış olan arazi kullanım türleri ve bunlara karşılık gelen kodlamaları Çizelge 5' de sunulmuştur. Program en uygun arazi kullanım türünün belirlenmesinde farklı ekolojilerde her bir AKT için belirlenen OBÜ ve KE değerlerini kullanmakta ve Oransal Haritalama Birimi Endeks (OHBE) değerleri elde edilmektedir. OHBE, her bir haritalama biriminin farklı arazi kullanım türlerinin arazi ve toprak isteklerini karlılık ile orantılı olarak ne kadar karşıladığını ifade eden skor değeridir aşağıdaki formülasyon ile belirlenmektedir.

$\mathrm{OHBE}=\mathrm{OBÜ} \times \mathrm{KE}$

Elde edilen OHBE değerleri ile çalışılan bölge arazilerinde en uygun ve karlı arazi kullanım türü hem çevresel hem de ekonomik kriterler göz önünde bulundurularak toprakların sahip olduğu üretkenlik potansiyeline göre belirlenmiş olmaktadır.

Cizelge 4. TKUS skor değerleri ve sınıfları (FAO, 1977)

\begin{tabular}{clcr}
\hline TKUS Sinifi & Skor & TKUS Sinifi & Skor \\
\hline S1 & $1.0-0.85$ & S6 & $0.40-0.49$ \\
S2 & $0.80-0.84$ & S7 & $0.30-0.39$ \\
S3 & $0.70-0.79$ & N1 & $0.20-0.29$ \\
S4 & $0.60-0.69$ & N2 & $0.10-0.19$ \\
\hline S5 & $0.50-0.59$ & N3 & $0-0.09$ \\
\hline
\end{tabular}

Çizelge 5. Arazi Kullanım Türleri (AKT) ve AKT'ye ait kodların Listesi

\begin{tabular}{|c|c|c|c|c|c|c|c|}
\hline KOD & ADI & KOD & ADI & KOD & ADI & KOD & ADI \\
\hline BB1 & Erik & SB46 & Hayvan Pancarı & BB27 & Kızılcık & TB24 & Susam \\
\hline BB2 & Şeftali & SB47 & Roka & BB28 & Paulownia & TB25 & Yerfıstığı \\
\hline BB3 & Kayısı-Zerdali & SB48 & Tere & BB29 & Trabzon hurması & KT1 & Buğday \\
\hline BB4 & $\mathrm{Bağg}$ & TB1 & Aspir & BB30 & Okaliptus & KT2 & Arpa \\
\hline BB5 & Badem & TB2 & Ayçiçeği & SB1 & Çilek & KT3 & Kimyon \\
\hline BB6 & Ceviz & TB3 & Kolza (Kanola) & SB2 & Kavun & KT4 & Yulaf \\
\hline BB7 & Elma & TB4 & Anason & SB3 & Karpuz & KT5 & Çavdar \\
\hline BB8 & Armut & TB5 & Haşhaş & SB4 & Lahana Grubu & KT6 & Tritikale \\
\hline BB9 & Kavak & TB6 & Şeker Pancarı & SB5 & Domates & KT7 & Burçak \\
\hline BB10 & Ayva & TB7 & Misir & SB6 & Patlican & KT8 & Mercimek \\
\hline BB11 & Dut & TB8 & Çeltik & SB7 & Biber & KT9 & Nohut \\
\hline BB12 & Vişne & TB9 & Soya & SB8 & Soğan & KT10 & Baklagiller \\
\hline BB13 & Kiraz & TB10 & Keten & SB9 & Sarımsak & KT11 & Bezelye \\
\hline BB14 & Nektarin & TB11 & Pamuk & SB10 & Kabak & KT12 & Antepfistığ 1 \\
\hline BB15 & Kuşburnu & TB12 & Tütün & SB11 & Hiyar & KT13 & Fiğ \\
\hline BB16 & $\begin{array}{l}\text { Ahududu- } \\
\text { Böğürtlen }\end{array}$ & TB13 & Kendir-Kenevir & SB12 & Acur & KT14 & Karayemiş \\
\hline BB17 & Muşmula & TB14 & Buğday & SB13 & Bamya & KT15 & Ayçiçeği \\
\hline BB18 & Portakal & TB15 & Arpa & SB14 & Ispanak & KT16 & Kapari \\
\hline BB19 & Mandalina & TB16 & Yulaf & SB15 & Havuç & KT17 & Kuşburnu \\
\hline BB20 & Turunç & TB17 & Çavdar & SB16 & Pazı & KT18 & Badem \\
\hline BB21 & Limon & TB18 & Tritikale & SB17 & Pırasa & KT19 & Ceviz \\
\hline BB22 & Greyfurt & TB19 & Burçak & SB18 & Turp & KT20 & Dut \\
\hline BB23 & Nar & TB20 & Yonca & SB19 & Marul & KT21 & Böğ̈ürtlen \\
\hline BB24 & Kivi & TB21 & Fiğ & SB20 & Fasulye & KT22 & Bağ \\
\hline BB25 & Avokado & TB22 & Korunga & SB21 & Maydanoz & KT23 & Vişne \\
\hline BB26 & Muz & TB23 & Sorgum & SB22 & Barbunya & KT24 & İğde \\
\hline SB23 & Karnabahar & KT25 & Kestane & & & & \\
\hline SB24 & Brokoli & KT26 & Zeytin & SB35 & Semizotu & TDK4 & Maden Ocakları \\
\hline SB25 & Patates & KT27 & İncir & SB36 & Brüksel Lahana & TDK5 & Yerleşke \\
\hline SB26 & Yer Elması & KT28 & Susam & SB37 & Nane & TDK6 & Sanayi Alanları \\
\hline SB27 & Kereviz & KT29 & Jojoba & SB38 & Dereotu & TDK7 & $\begin{array}{l}\text { Kum ve Çakıl } \\
\text { Ocakları }\end{array}$ \\
\hline SB28 & Enginar & KT30 & Keçiboynuzu & SB39 & Rezene & TDK8 & Rekreasyon \\
\hline
\end{tabular}




\begin{tabular}{|c|c|c|c|c|c|c|c|}
\hline KOD & $\mathrm{ADI}$ & KOD & $\mathrm{ADI}$ & KOD & ADI & KOD & ADI \\
\hline & & & & & & & Alanları \\
\hline SB29 & Bakla & KT31 & Kavun- Karpuz & SB40 & Tarhun & TDK9 & Hava Alanları \\
\hline SB30 & Yemeklik Pancar & KT32 & Çay & SB41 & Zahter & TDK10 & $\begin{array}{l}\text { Kültür Ve Spor } \\
\text { Kompleksleri }\end{array}$ \\
\hline SB31 & Şalgam & KT33 & Findık & SB42 & Kekik & TDK11 & $\begin{array}{ll}\text { Katı Attklar Ve } \\
\text { Arıtma Deposu }\end{array}$ \\
\hline SB32 & Kuşkonmaz & TDK1 & Çayır-Mera & SB43 & Mercan Köşk & TDK12 & $\begin{array}{l}\text { Tarımsal İşletme } \\
\text { Ve Depolar }\end{array}$ \\
\hline SB33 & Ravent & TDK2 & Orman & SB44 & Kuş Dili & TDK13 & $\begin{array}{l}\text { Turistik Ve } \\
\text { Dinlenme Tesisler }\end{array}$ \\
\hline SB34 & Hindi bağ1 & TDK3 & $\begin{array}{l}\text { Taş ve Tuğla } \\
\text { Ocakları }\end{array}$ & SB45 & Börülce & TDK14 & $\begin{array}{ll}\text { Ulaşım } & \text { Ve } \\
\text { Haberleşme } & \\
\text { Yatırım Alanı } & \\
\end{array}$ \\
\hline
\end{tabular}

\section{Bulgular ve Tartışma}

\section{Tarımsal kullanıma uygunluk sınıflaması}

Kalecik ilçesine ait yaklaşı 116025,3 ha alana ait arazilerde ayırt edilmiş olan 1518 adet haritalama biriminin, değerlendirmeye alınan tarımsal amaçlı arazi kullanım türlerine (AKT) uygunluk derecesini yansitan Haritalama Birimi Endeksleri (HBE) elde edilmiştir. HBE'lerden elde edilen OHBE değerleri Çizelge 6'da belirtilen sınır değerleri doğrultusunda gruplandırılarak, araştırma alanında yer alan tüm araziler, tarımsal kullanıma uygunluk yönünden sınıflandırılmıştır. Etüt alanı topraklarının program ile değerlendirilmesi sonucu her bir haritalama birimine ait Tarımsal Kullanıma Uygunluk Sinıfları (TKUS) ve haritalama birimlerinin ŞADY'e tanımlı olan 150 bitki türü için Oransal Haritalama Birimi Endeks (OHBE) değerleri belirlenmiştir. Programa tanımlanmış olan her bir arazi karakteristiği ve bunların etki dereceleri ile programa tanımlı 150 bitkinin oransal beklenen ürün endeksleri (OBÜ) belirlenmiştir. Ürün endeksleri ile birlikte TKUS ve OHBE değerlerinin hesaplanmasında Şenol (1983) ve Tarım Reformu Genel Müdürlüğü tarafindan çeşitli üniversitelerden bilim insanlarına ve kendi bünyesinde çalışan agronomistlere dayanılarak hazırlanan "Arazi Derecelendirmesine Esas Toprak Puanı Hesabı" kullanılmıştır.

Program değerlendirmesi sonucu araştırma alanında 4562,4 ha (\% 3,9) arazinin "iyi" "S1", 2761,1 ha $(\% 2,4)$ arazinin "orta" "S2" ve 14605,6 ha (\% 12,6) arazinin "az" "S3" tarımsal kullanıma uygunluk sınıflarında nitelendirilmiştir. Çalışma alanını tarımsal kullanıma uygunluk sınıflaması dağılımı Çizelge 6 ve Şekil 5 de verilmiştir.

Çizelge 6. Çalışma alanı Tarımsal Kullanıma Uygunluk Sınıflarına ait alansal ve oransal dağılımları

\begin{tabular}{lrrrrr}
\hline & \multicolumn{2}{c}{ Alan } & \multicolumn{2}{c}{ Uygunluk Sinıf } & Alan \\
Uygunluk Sinıf & ha & $\%$ & & 10979,4 & 9,5 \\
S1 & 4562,4 & 3,9 & S6 & 8108,6 & 7,0 \\
S2 & 2761,1 & 2,4 & S7 & 6498,2 & 5,6 \\
S3 & 14605,6 & 12,6 & N1 & 1859,1 & 1,6 \\
S4 & 15247,5 & 13,1 & N2 & 40328,1 & 34,8 \\
S5 & 11075,3 & 9,5 & N3 & 116025.3 & 100,0 \\
Toplam & & & & & \\
\hline
\end{tabular}

Arazinin yaklaşık \% 42'sine karş1lı gelen 48685,4 ha alan ise N (1, 2 ve 3 olmak üzere) sembolü ile gösterilen ve tarımsal kullanımlar için hiç uygun olmayan alanları oluşturmaktadır. Buna karşlık arazilerin tarımsal faaliyetler karşısında toprakların özellikle risk altında olduğu özellikle tarımsal kullanım sınıfları içerisinde S4, S5, S6 ve S7 seviyesinde olan marjinal veya mevcut haliyle tarımsal kullanıma imkan vermeyen alanlarda özellikle toprak çok sığlığı, fazla eğim ve erozyon tehlikesi bulunmaktadır. Ayrıca bu alanların birçoğunda işlemeli tarımın yapılmasında sınırlayıcı faktörler olarak yüksek kayalı1ık ve taşl11ık problemleri de bulunmaktadır. 


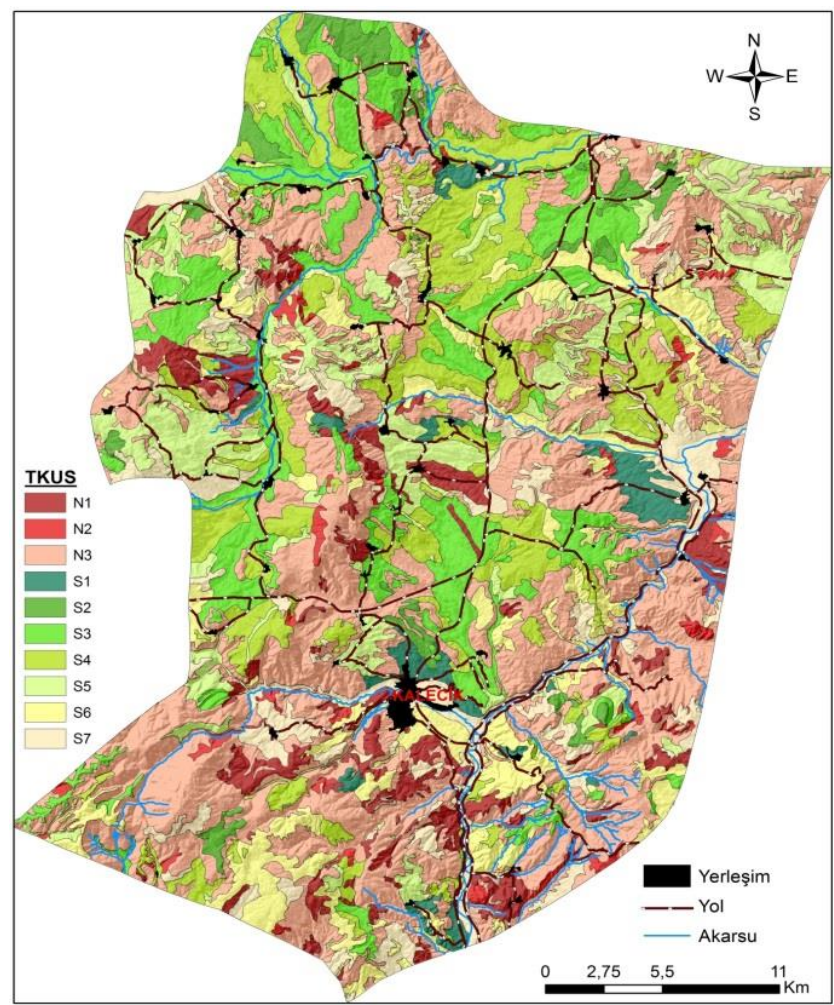

Şekil 5. Çalışma alanı Tarımsal Kullanım Uygunluk Sınıflaması dağı̆ım haritası

Kalecik İlçesi arazileri için bahçe bitkileri (sebze, meyve ve bağ olmak üzere), tarla bitkileri, kuru tarım ve çayır-mera alanlarına ait dağılım desenleri Şekil 9 da verilmiştir. Buna göre bahçe bitkileri tarımı olarak ele alınan erik, şeftali, kayısı, bağ, badem, ceviz, elma, armut, kavak, ayva, dut, vişne, kiraz, nektarin, ahududu ve kızılcık bitkilerine yönelik potansiyel kullanım durumu dikkate alındığında genel olarak bahçe bitkileri tarımına yönelik toplam alanın \%60,6'sı (70330,7 ha) uygunluk göstermektedir. Ayrıca, alan içerisinde bahçe bitkilerine ait potansiyel kullanım grupları ve dağılım oranları Çizelge 7'de verilmiştir. Araştırma alanında \%18,4 ile en fazla yayılım gösteren bahçe bitkileri potansiyel kullanım grupları erik, şeftali, kayısı-zerdali, bağ, badem, ceviz, elma, armut, kavak, ayva, dut, vişne, kiraz, nektarin, ahududu-böğürtlen grubudur. Buna karş1lı en az dağılım gösteren grup ise 45,5 ha ile bağ, ahududu-böğürtlen, kızılcık grubudur. Bahçe bitkilerine yönelik olarak İlçe için hazırlanan veri tabanından bazı arazi kullanım türlerine yönelik olarak örneğin badem, bağ, kaysı, elma, vişne, ceviz, ayva, armut ve erik bitkilerinin İlçe sınırları içerisinde dağılım durumları ve uygunluk sınıflarını gösteren harita örnekleri verilmiştir (Şekil 6).

Kalecik İlçesi arazileri için sebze bitkileri tarımı olarak ele alınan çilek, kavun, karpuz, lahana, domates, patlıcan, biber, soğan, sarımsak, kabak, hıyar, acur, bamya, ıspanak, havuç, pazı, pırasa, turp, marul, fasulye, maydanoz, barbunya, karnabahar, brokoli, patates, bakla, yemeklik pancar, şalgam, bürüksel lahanası, nane ve dereotu bitkilerine yönelik potansiyel kullanım durumu dikkate alındığında genel olarak sebze bitkileri tarımına yönelik toplam alanın \%41,1'i (47717,8 ha) uygunluk göstermektedir. Alan içerisinde sebze bitkilerine ait potansiyel kullanım grupları ve dağılım oranları Çizelge 8 ' de verilmiştir. Alanda \%9,89 ile en fazla yayılım gösteren sebze ve meyve bitkileri potansiyel kullanım grupları çilek, kavun, karpuz, lahana grubu, domates, patlıcan, biber, soğan, sarımsak, kabak, hıyar, acur, bamya, ıspanak, havuç, pazı, pırasa, turp, marul, fasulye, maydanoz, barbunya, karnabahar, patates, bakla, yemeklik pancar, şalgam, nane, dereotu, hayvan pancarı grubudur. Buna karşı1ık en az dağılım gösteren grup ise 77,4 ha ile domates, kabak, hıyar ve bamya grubudur. Sebze bitkilerine yönelik olarak İlçe için hazırlanan veri tabanından bazı arazi kullanım türlerine yönelik olarak örneğin kavun-karpuz, soğan- sarımsak, domates, kabak-hıyar, biber, fasulye, patates, lahana ve patlıcan bitkilerinin İlçe sınırları içerisinde dağılım durumları ve uygunluk sınıflarını gösteren harita örnekleri verilmiştir (Şekil 7). 
ÇOMÜ Zir. Fak. Derg. (COMU J. Agric. Fac.)

2021: 9 (2): $339-358$

ISSN: 2147-8384 / e-ISSN: 2564-6826

doi: $10.33202 /$ comuagri.964808

Çizelge 7. Kalecik İlçesi bahçe bitkileri potansiyel tarımsal kullanım grupları ve dağılım oranları

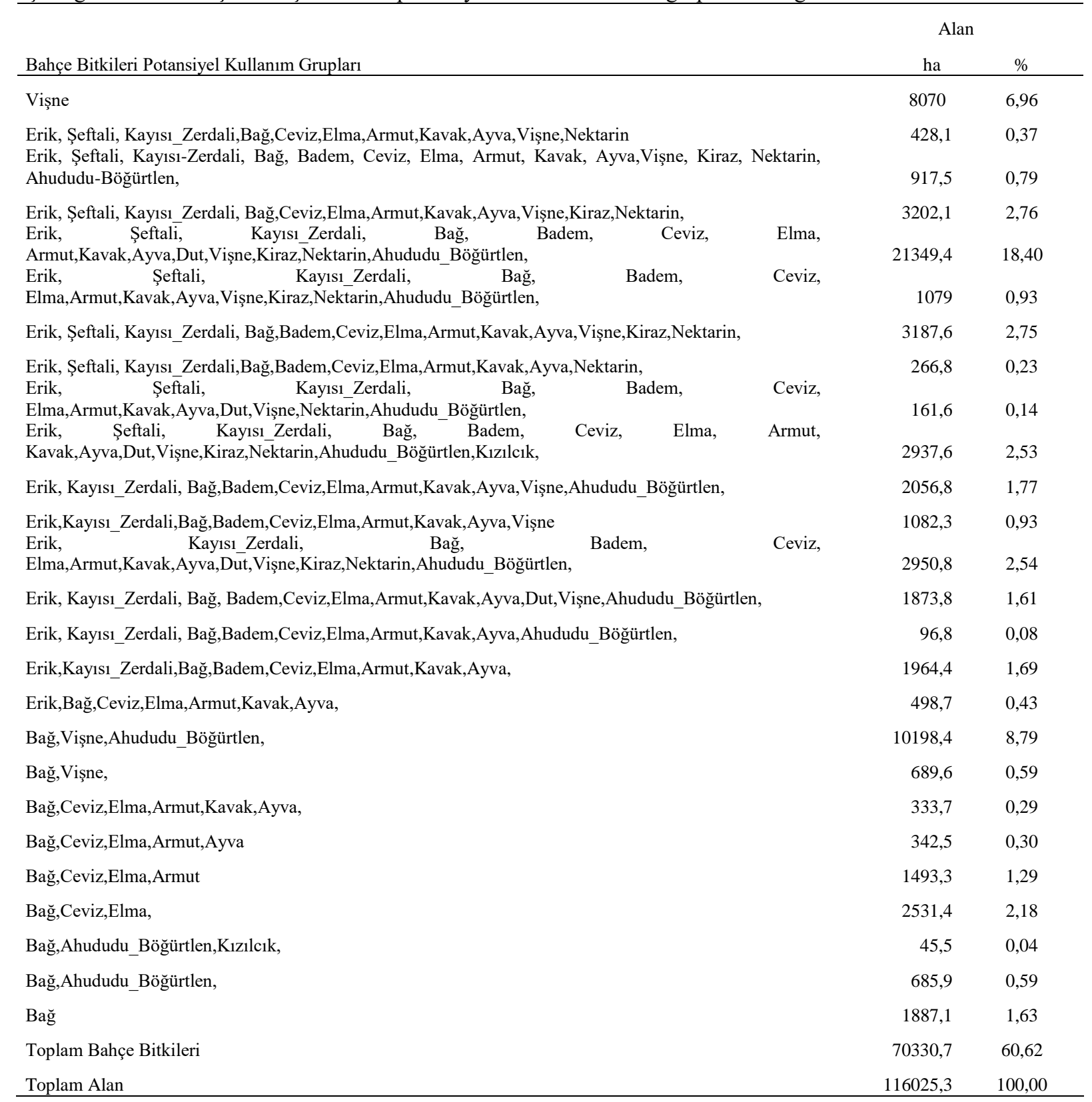



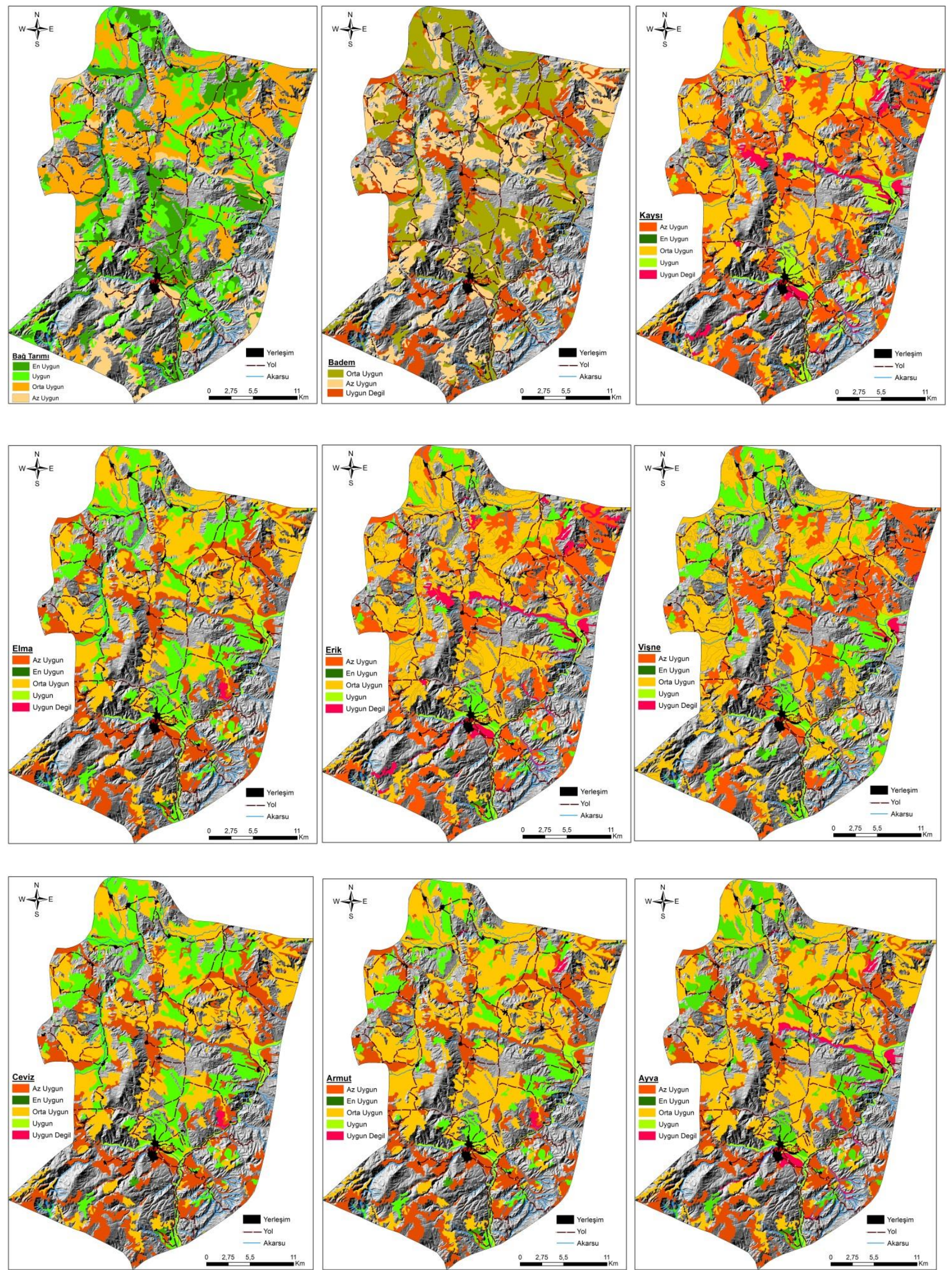

Şekil 6. Bazı bahçe bitkileri arazi kullanım türlerine ait uygunluk dağılım haritaları 
Çizelge 8. Kalecik İlçesi sebze bitkileri potansiyel tarımsal kullanım grupları ve dağılım oranları

Sebze Bitkileri Potansiyel Kullanım Grupları

Kavun, Karpuz, Lahana Grubu, Domates, Patlıcan, Soğan, Kabak, Hiyar, Bamya, Karnabahar, Patates,

$1843,3 \quad 1,59$

Kavun, Karpuz, Lahana Grubu, Domates, Patlıcan, Biber, Soğan, Sarımsak, Kabak, Hıyar, Bamya, Ispanak, Havuç, Pazı, Turp, Fasulye, Patates, Şalgam, Nane, Dereotu,

Kavun, Karpuz, Lahana Grubu, Domates, Patlıcan, Biber, Soğan, Sarımsak, Kabak, Hıyar, Acur, Bamya, Ispanak, Havuç, Turp, Fasulye, Karnabahar, Patates, Şalgam, Nane, Dereotu,

Kavun, Karpuz, Lahana Grubu, Domates, Patlıcan, Biber, Soğan, Sarımsak, Kabak, Hıyar, Acur, Bamya, Ispanak, Havuç, Pazı, Turp, Marul, Fasulye,

Karnabahar, Patates, Yemeklik Pancar, Salgam, Nane, Dereotu, Hayvan Pancarı,

$360,1 \quad 0,31$

$212,3 \quad 0,18$

$1082,3 \quad 0,93$

Kavun, Karpuz, Lahana Grubu, Domates, Patlıcan, Biber, Soğan, Sarımsak, Kabak, Hıyar, Acur, Bamya, Ispanak, Havuç, Pazı, Turp, Marul, Fasulye, Karnabahar, Patates,Yemeklik Pancar, Şalgam, Brüksel Lahana, Nane, Dereotu, Hayvan Pancarı,

Kavun,Karpuz,Lahana

Grubu,Domates,Patlıcan,Biber,Soğan,Sarımsak,Kabak,Hıyar,Acur,Bamya,Ispanak,Havuç,Pazı,Turp,Fasülye,Karnıba har,Patates, Yemeklik Pancar,Şalgam,Nane,Dereotu,Hayvan Pancarı,

Kavun,Karpuz,Lahana

Grubu,Domates,Patlıcan,Biber,Soğan,Sarımsak,Kabak,Hıyar,Acur,Bamya,Ispanak,Havuç,Pazı,Turp,Fasülye,Karnıba har,Patates,Yemeklik Pancar,Şalgam,Brüksel Lahana,Nane,Dereotu,Hayvan Pancarı,

Kavun,Karpuz,Lahana

Grubu,Domates,Patlıcan,Biber,Soğan,Sarımsak,Kabak,Hıyar,Acur,Bamya,Ispanak,Havuç,Pazı,Turp,Fasülye,Karnıba har,Patates,Şalgam,Nane,Dereotu,

Kavun,Karpuz,Lahana

Grubu,Domates,Patlıcan,Biber,Soğan,Kabak,Hıyar,Bamya,Havuç,Turp,Fasülye,Patates,Şalgam,

Kavun,Karpuz,Lahana Grubu,Domates,Patlıcan,Biber,Soğan,Kabak,Hıyar,Bamya,Havuç,Turp,Fasülye,Patates,

Kavun,Karpuz,Lahana Grubu,Domates,Patlıcan,Biber,Soğan,Kabak,Hıyar,Bamya,Havuç,Patates,

Kavun,Karpuz,Lahana

Grubu,Domates,Patlıcan,Biber,Soğan,Kabak,Hıyar,Bamya,Havuç,Fasülye,Karnıbahar,Patates,Şalgam,

Domates,Kabak,Hiyar,Bamya,

Cilek,Kavun,Karpuz,Lahana

Grubu,Domates,Patlıcan,Biber,Soğan,Sarımsak,Kabak,Hıyar,Acur,Bamya,Ispanak,Havuç,Pırasa,Turp,Marul,Fasülye, Maydonoz,Barbunya,Karnıbahar,Patates,Şalgam,

Cilek,Kavun,Karpuz,Lahana

Grubu,Domates,Patlıcan,Biber,Soğan,Sarımsak,Kabak,Hıyar,Acur,Bamya,Ispanak,Havuç,Pazı,Pırasa,Turp,Marul,Fas ülye,Maydonoz,Barbunya,Karnıbahar,Patates,Bakla,Yemeklik Pancar,Şalgam,Nane,Dereotu,Hayvan Pancarı,

Çilek,Kavun,Karpuz,Lahana

Grubu,Domates,Patlıcan,Biber,Soğan,Sarımsak,Kabak,Hıyar,Acur,Bamya,Ispanak,Havuç,Pazı,Pırasa,Turp,Marul,Fas ülye,Maydonoz,Barbunya,Karnıbahar,Patates,Bakla,Yemeklik Pancar,Şalgam,Brüksel Lahana,Nane,Dereotu,Hayvan Pancarı,

Cilek,Kavun,Karpuz,Lahana

Grubu,Domates,Patlıcan,Biber,Soğan,Sarımsak,Kabak,Hıyar,Acur,Bamya,Ispanak,Havuç,Pazı,Pırasa,Turp,Marul,Fas ülye,Maydonoz,Barbunya,Karnıbahar,Brokoli,Patates,Bakla,Yemeklik

Lahana,Nane,Dereotu,Hayvan Pancarı,

Pancar,Şalgam,Brüksel

Çilek,Kavun,Karpuz,Lahana

Grubu,Domates,Patlıcan,Biber,Soğan,Sarımsak,Kabak,Hıyar,Acur,Bamya,Ispanak,Havuç,Pazı,Pırasa,Turp,Marul,Fas ülye,Barbunya,Karnıbahar,Patates,Yemeklik Pancar,Şalgam,Nane,Dereotu,Hayvan Pancarı,

Çilek,Kavun,Karpuz,Lahana

Grubu,Domates,Patlıcan,Biber,Soğan,Kabak,Hıyar,Bamya,Havuç,Turp,Fasülye,Karnıbahar,Patates,Şalgam

Çilek, Kavun, Karpuz, Lahana Grubu, Domates, Patlıcan,Biber,Soğan,Kabak,Hıyar,Bamya,Havuç,Fasülye,Patates,

Çilek, Kavun, Karpuz, Lahana Grubu, Domates, Patlican,

Biber,Soğan,Kabak,Hıyar,Bamya,Havuç,Fasülye,Karnıbahar,Patates, Şalgam,

Çilek, Kavun, Karpuz, Lahana Grubu,

Biber,Soğan,Kabak,Hiyar,Bamya,Havuç,Fasülye,Karnıbahar,Patates,

Domates,

Patlican, 
ÇOMÜ Zir. Fak. Derg. (COMU J. Agric. Fac.)

2021: 9 (2): 339-358

ISSN: 2147-8384 / e-ISSN: 2564-6826

doi: $10.33202 /$ comuagri. 964808
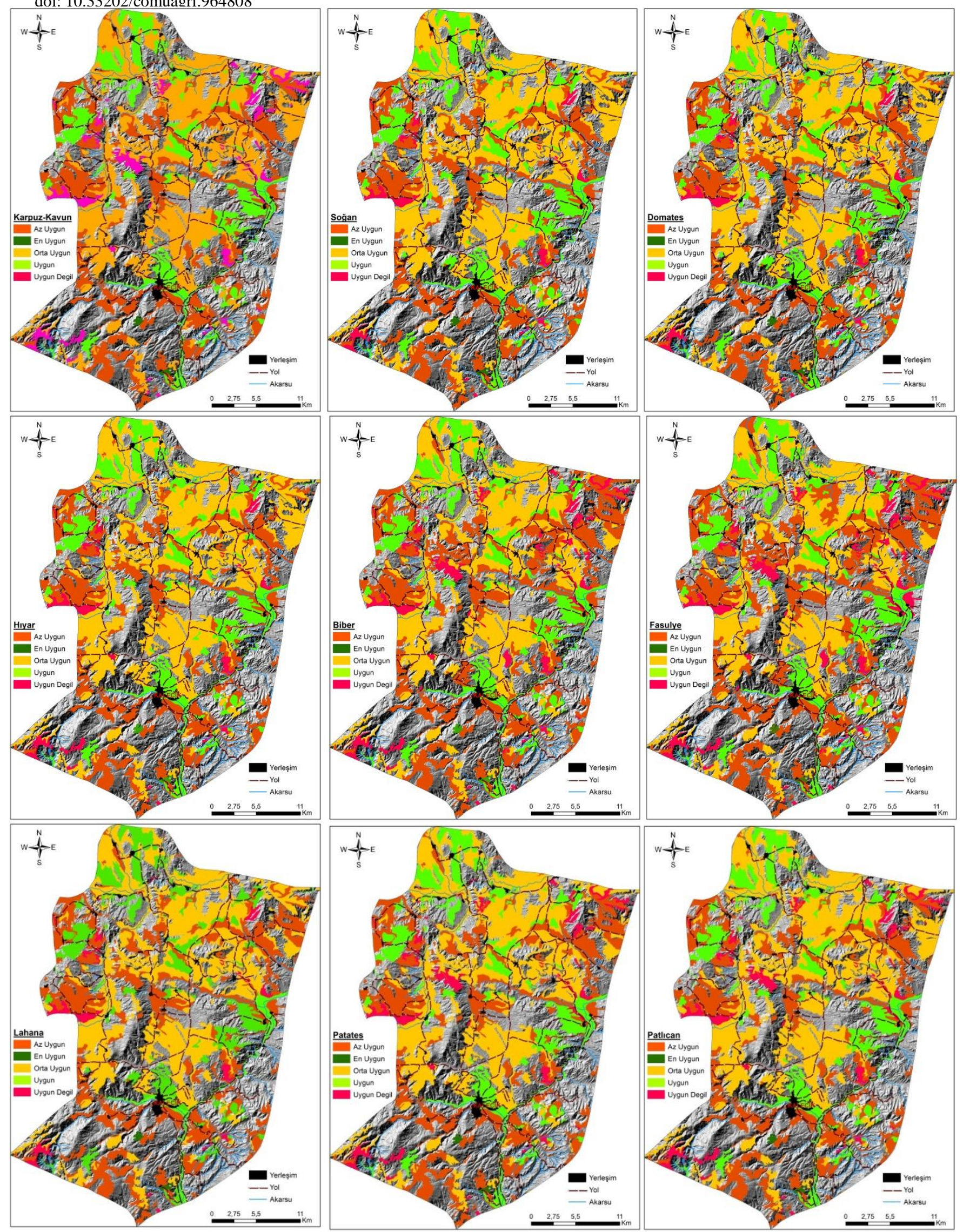

Şekil 7. Bazı sebze bitkileri arazi kullanım türlerine ait uygunluk dağılım haritaları 
Kalecik İlçesi arazileri için tarla bitkileri tarımı olarak ele alınan aspir, ayçiçeği, şeker pancarı, mısır, çeltik, buğday, arpa, kimyon, çavdar, tritikale, burçak, yonca, fiğ, kimyon ve sorgum bitkilerine yönelik potansiyel kullanım durumu dikkate alındığında genel olarak tarla bitkileri tarımına yönelik toplam alanın \% 49,1'i (56969,8 ha) uygunluk göstermektedir. Alan içerisinde tarla bitkilerine ait potansiyel kullanım grupları ve dağılım oranları Çizelge 9'da verilmiştir. Araştırma alanında \%17,1 ile en fazla yayılım gösteren tarla bitkileri potansiyel kullanım grupları aspir, ayçiçeği, şeker pancarı, misır, buğday, arpa, kimyon, çavdar, tritikale, burçak, fiğg, korunga, sorgum grubudur. Buna karşl1ı en az dağılım gösteren grup ise 137,6 ha ile ayçiçeği, şeker pancarı, mısır, buğday, arpa, tritikale, yonca, fiğ ve korunga grubudur. Tarla bitkilerine yönelik olarak İlçe için hazırlanan veri tabanından bazı arazi kullanım türlerine yönelik olarak örneğin ayçiçeği, buğday, arpa, yonca, fiğg, korunga, mısır, aspir ve çavdar bitkilerinin İlçe sınırları içerisinde dağılım durumları ve uygunluk sınıflarını gösteren harita örnekleri verilmiştir (Şekil 8).

Çizelge 9. Kalecik İlçesi tarla bitkileri potansiyel tarımsal kullanım grupları ve dağılım oranları

\begin{tabular}{|c|c|c|}
\hline \multirow[b]{2}{*}{ Tarla Bitkileri Potansiyel Kullanım Grupları } & \multicolumn{2}{|l|}{ Alan } \\
\hline & ha & $\%$ \\
\hline Şeker Pancarı,Buğday,Arpa,Tritikale,Fiğ,Korunga, & 1605,8 & 1,4 \\
\hline ŞekerPancarı, Buğday,Arpa,Kimyon,Çavdar,Tritikale,Burçak,Fiğ,Korunga, & 265,0 & 0,2 \\
\hline Şeker Pancarı,Arpa,Fiğ,Korunga, & 77,4 & 0,1 \\
\hline Çeltik, & 180,0 & 0,2 \\
\hline Buğday,Arpa,Tritikale, & 2168,6 & 1,9 \\
\hline Ayçiçeği,Şeker Pancarı,Mısır,Buğday,Arpa,Tritikale,Yonca,Fiğ,Korunga, & 137,6 & 0,1 \\
\hline Ayçiçeği,Şeker Pancarı,Mısır,Buğday,Arpa,Kimyon,Çavdar,Tritikale,Burçak,Yonca,Fiğ, Korunga, & 1265,4 & 1,1 \\
\hline Ayçiçeği,Şeker Pancarı,Buğday,Arpa,Tritikale,Yonca,Fiğ,Korunga, & 372,6 & 0,3 \\
\hline Ayçiçeği,Şeker Pancarı,Buğday,Arpa,Tritikale,Fiğ,Korunga, & 1299,8 & 1,1 \\
\hline Ayçiçeği,Şeker Pancarı,Buğday,Arpa,Kimyon,Çavdar,Tritikale,Burçak,Yonca,Fiğ, Korunga, & 415,9 & 0,4 \\
\hline Ayçiçeği,Şeker Pancarı,Buğday,Arpa,Kimyon,Çavdar,Tritikale,Burçak,Fiğ,Korunga,Sorgum, & 647,0 & 0,6 \\
\hline Ayçiçeği, ŞekerPancarı,Buğday,Arpa,Kimyon,Çavdar,Tritikale,Burçak,Fiğ,Korunga, & 580,0 & 0,5 \\
\hline $\begin{array}{l}\text { Ayçiçeği, } \\
\text { Aspir,Ayçiçeği,Şeker }\end{array}$ & 21,0 & 0,0 \\
\hline Pancarı,Mısır,Çeltik,Buğday,Arpa,Kimyon,Çavdar,Tritikale,Burçak,Yonca,Fĭ̆,Korunga,Sorgum, & 16529,0 & 14,2 \\
\hline Aspir,Ayçiçeği,Şeker Pancarı,Mısır,Çeltik,Buğday,Arpa,Kimyon,Çavdar,Tritikale,Burçak, Yonca,Fiğ,Korunga, & 1062,4 & 0,9 \\
\hline Aspir,Ayçiçeği,Şeker Pancarı,Mısır,Buğday,Arpa,Tritikale,Yonca,Fiğ,Korunga, & 339,0 & 0,3 \\
\hline Aspir,Ayçiçeği,Şeker Pancarı,Mısır,Buğday,Arpa,Tritikale,Fiğ,Korunga, & 374,5 & 0,3 \\
\hline Aspir,Ayçiçeği,Şeker Pancarı,Mısır,Buğday,Arpa,Kimyon,Çavdar,Tritikale,Burçak,Yonca,Fiğ,Korunga,Sorgum & 2906,8 & 2,5 \\
\hline Aspir,Ayçiçeği,Şeker Pancarı,Mısır,Buğday,Arpa,Kimyon,Çavdar,Tritikale,Burçak,Yonca,Fiğ,Korunga, & 378,3 & 0,3 \\
\hline Aspir,Ayçiçeği,Şeker Pancarı,Mısır,Buğday,Arpa,Kimyon,Çavdar,Tritikale,Burçak,Fiğ,Korunga,Sorgum, & 19877,8 & 17,1 \\
\hline Aspir,Ayçiçeği,Şeker Pancarı,Mısır,Buğday,Arpa,Kimyon,Çavdar,Tritikale,Burçak,Fiğ,Korunga, & 6401,5 & 5,5 \\
\hline Arpa & 64,5 & 0,1 \\
\hline Toplam Tarla Bitkileri & 56969,8 & 49,1 \\
\hline Toplam Alan & 116025,3 & 100,0 \\
\hline
\end{tabular}


ÇOMÜ Zir. Fak. Derg. (COMU J. Agric. Fac.)

2021: 9 (2): 339-358

ISSN: $2147-8384$ / e-ISSN: 2564-6826

doi: 10.33202/comuagri.964808
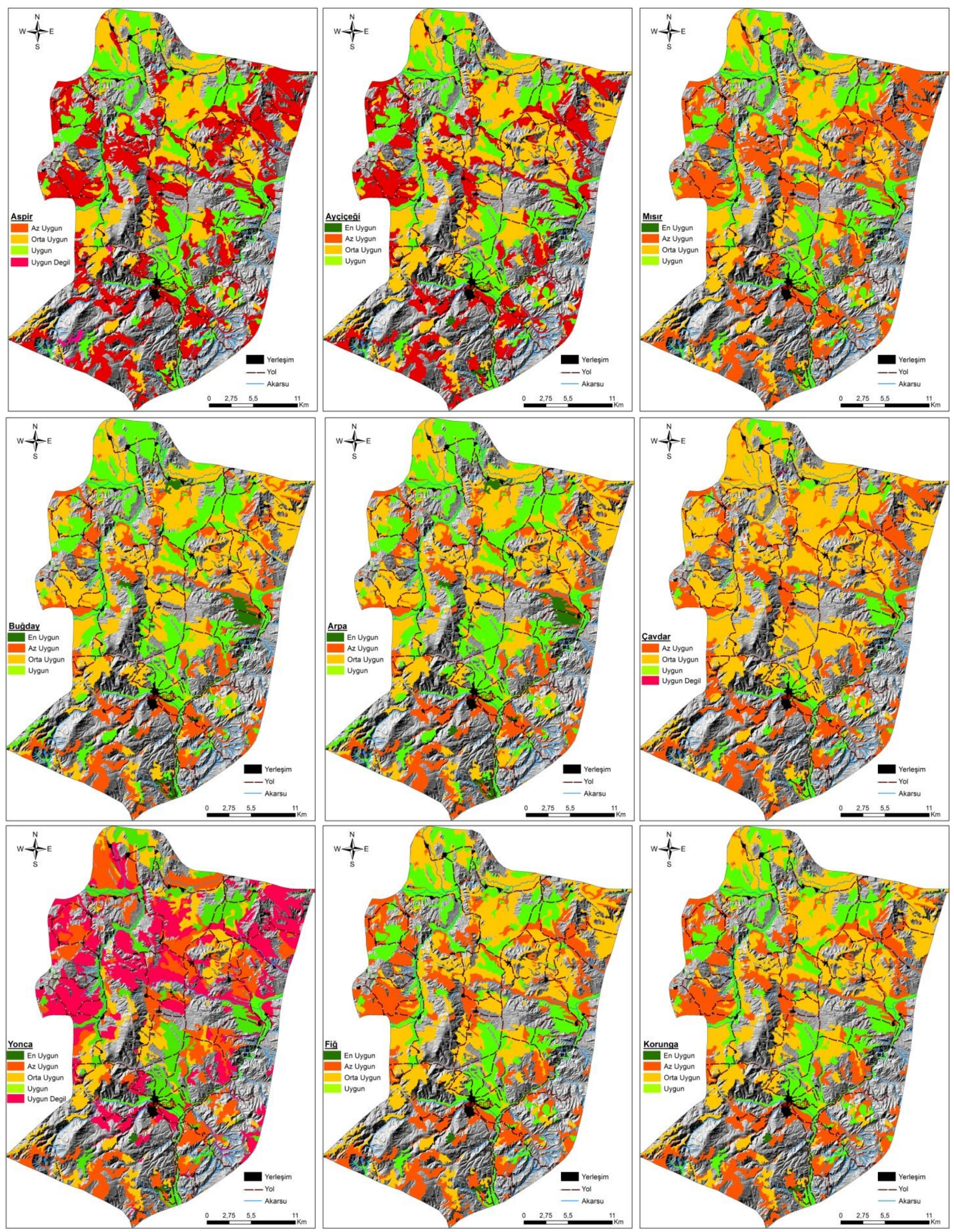

Şekil 8. Bazı tarla bitkileri arazi kullanım türlerine ait uygunluk dağılım haritaları 
Kalecik İlçesi kuru tarım arazi kullanım türlerine (bahçe ve tarla bitkileri olmak üzere) yönelik olarak yoğunluk dağılımları Çizelge 10 ve Şekil 9'da verilmiştir. Genel olarak ilçe arazilerinin kuru tarıma yönelik toplam alanın \% 55,02'si (63837,9 ha) uygunluk göstermektedir. Alan içerisinde en fazla \%13,04'lük kısmı buğday, arpa, kimyon, yulaf, çavdar, tritikale, burçak, mercimek, nohut, baklagil, bezelye, fiğ, ayçiçeği, kapari, kuşburnu, badem, ceviz, dut, böğürtlen, bağ, vişne, iğde, kavun-karpuz grubuna ait potansiyel kullanım kuruda tarım yapmaya elverişi olduğu belirlenmiştir.

Çizelge 10. Kalecik İlçesi bahçe ve tarla bitkileri potansiyel tarımsal kullanım grupları ve dağlım oranları

\begin{tabular}{|c|c|c|}
\hline \multirow[b]{2}{*}{ Kuru Tarım Bitkileri Potansiyel Kullanım Grupları } & \multicolumn{2}{|c|}{ Alan } \\
\hline & ha & $\%$ \\
\hline Kavun_Karpuz, & 228,2 & 0,20 \\
\hline Kapari,Kuşburnu,Böğürtlen,Bağ & 114,9 & 0,10 \\
\hline Kapari,Kuşburnu,Bağ, & 68,4 & 0,06 \\
\hline Ceviz,Bağ,Vişne, & 90,9 & 0,08 \\
\hline Buğday, Arpa, Yulaf, Çavdar,Tritikale,Mercimek,Nohut,Fiğ,Bağ,Vişne,Kavun_Karpuz, & 71,3 & 0,06 \\
\hline Buğday, Arpa,Yulaf,Çavdar,Tritikale,Mercimek,Nohut,Fiğ,Bağ,Vişne, & 902,6 & 0,78 \\
\hline Buğday, Arpa, Yulaf, Çavdar, Tritikale, Mercimek,Nohut,Fiğ,Badem,Ceviz,Bağ,Vişne,Kavun_Karpuz, & 2022,3 & 1,74 \\
\hline Buğday, Arpa,Yulaf,Çavdar,Tritikale,Mercimek,Nohut,Fiğ,Badem,Bă̆,Vişne, & 580,9 & 0,50 \\
\hline Buğday, Arpa, Yulaf, Çavdar, Tritikale, Mercimek,Nohut,Fiğ,Ayçiçeği,Badem,Ceviz,Bağ,Vişne,Kavun_Karpuz, & 479,4 & 0,41 \\
\hline Buğday, Arpa, Yulaf, Çavdar, Tritikale,Mercimek,Nohut,Fiğ,Ayçiçeği,Badem,Ceviz,Bağ,Vişne, & 900,2 & 0,78 \\
\hline Buğday, Arpa, Yulaf, Çavdar, Tritikale, Mercimek,Nohut,Fiğ,Ayçiçeği,Badem,Bağ,Vişne,Kavun_Karpuz, & 31,3 & 0,03 \\
\hline Buğday, Arpa, Yulaf, Çavdar,Tritikale,Mercimek,Nohut,Fiğ,Ayçiçeği,Badem,Bağ,Vişne, & 12,1 & 0,01 \\
\hline Buğday, Arpa, Yulaf,Çavdar,Tritikale,Burçak,Mercimek,Nohut,Fiğ,Bağ,Vişne, & 53,9 & 0,05 \\
\hline Buğday, Arpa, Yulaf, Çavdar, Tritikale, Burçak, Mercimek,Nohut,Fiğ,Badem,Ceviz,Bağ,Vişne,İğde,Kavun_Karpuz, & 7,6 & 0,01 \\
\hline 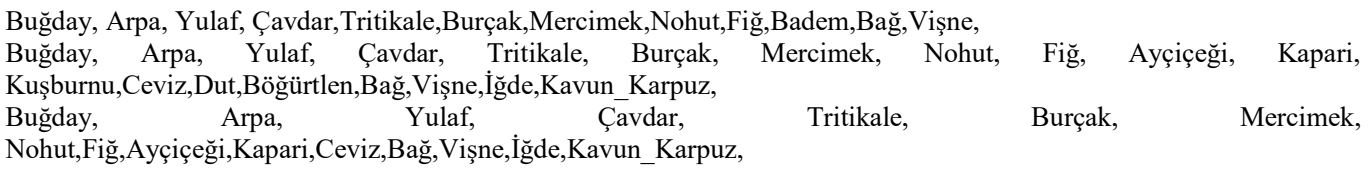 & $\begin{array}{r}242,8 \\
1026,0 \\
96,8\end{array}$ & 0,21 \\
\hline 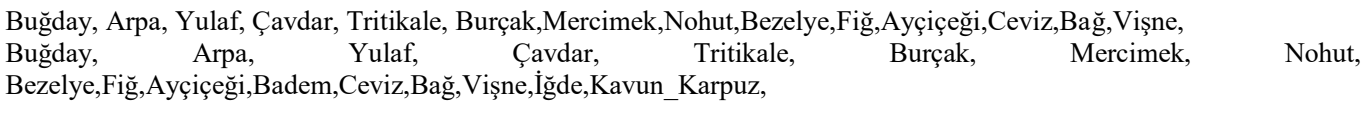 & $\begin{array}{l}446,1 \\
208,9\end{array}$ & 0,18 \\
\hline 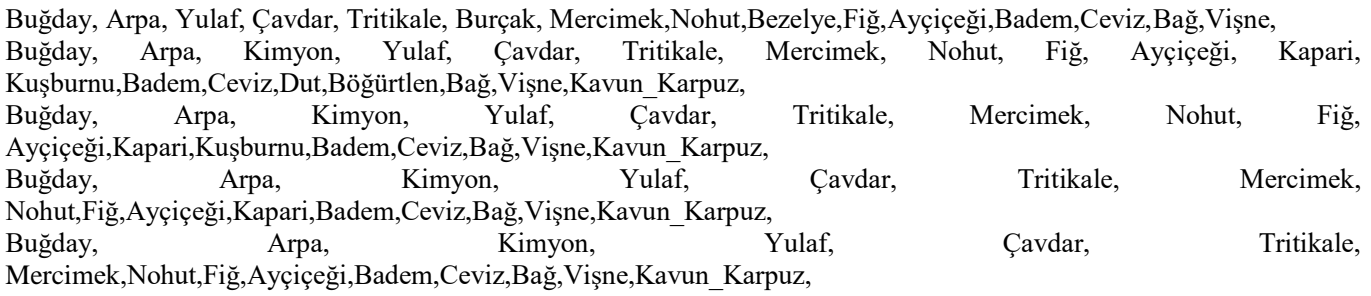 & $\begin{array}{r}43,2 \\
10527,1 \\
235,1 \\
3613,8 \\
3015,8\end{array}$ & 3,11 \\
\hline $\begin{array}{l}\text { Buğday, Arpa, Kimyon, Yulaf, Çavdar, Tritikale,Mercimek,Nohut,Fiğ,Ayçiçeği,Badem,Ceviz,Bağ,Vişne, } \\
\text { Buğday, Arpa, Kimyon, Yulaf, Çavdar, Tritikale, Burçak, Mercimek, Nohut, Fiğ, Ayçiçeği, Kapari, } \\
\text { Kuşburnu,Badem,Ceviz,Dut,Böğ̈urtlen,Bağ,Vişne,İğde,Kavun_Karpuz, }\end{array}$ & $\begin{array}{r}2508,1 \\
40,2\end{array}$ & 0,03 \\
\hline 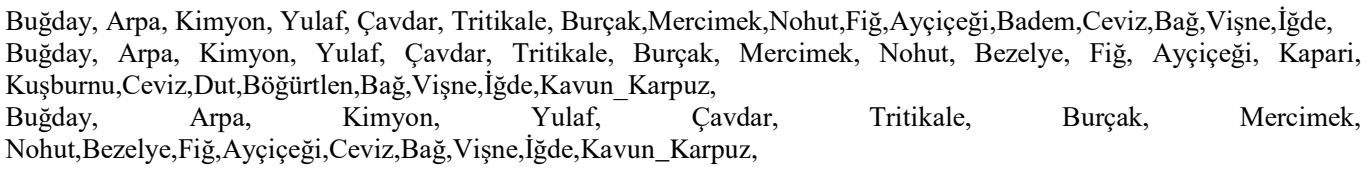 & $\begin{array}{r}2374,5 \\
109,2\end{array}$ & 0,09 \\
\hline Buğday, Arpa, Kimyon, Yulaf, Çavdar, Tritikale, Burçak, Mercimek,Nohut,Bezelye,Fiğ,Ayçiçeği,Ceviz,Bağ,Vişne,Ĭğde, & 671,4 & 0,58 \\
\hline 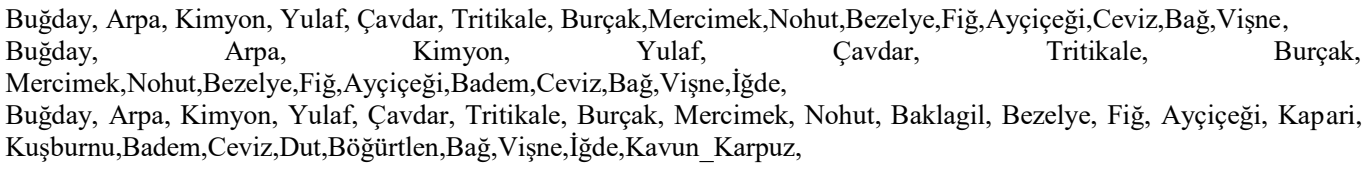 & $\begin{array}{r}60,9 \\
1299,5\end{array}$ & 13,04 \\
\hline Arpa, Kimyon, Yulaf, Çavdar, Tritikale, & 1257,9 & 1,08 \\
\hline
\end{tabular}


ÇOMÜ Zir. Fak. Derg. (COMU J. Agric. Fac.)

2021: 9 (2): 339-358

ISSN: $2147-8384$ / e-ISSN: 2564-6826

doi: 10.33202/comuagri.964808

Bezelye,Fiğ,Ayçiçeği,Ceviz,Bağ,Vişne,Iğde,Kavun_Karpuz,

Buğday, Arpa, Kimyon, Yulaf, Çavdar, Tritikale, Burçak, Mercimek,

Nohut,Baklagil,Bezelye,Fiğ,Ayçiçeği,Ceviz,Bağ,Vişne,Ĭğde,

Buğday, Arpa, Kimyon, Yulaf, Çavdar, Tritikale, Burçak, Mercimek, Nohut, Baklagil,

Bezelye,Fiğ,Ayçiçeği,Badem,Ceviz,Bă̆,Vișne,Ĭğde,Kavun Karpuz, Arpa,

Kimyon,

$\begin{array}{rr}64,4 & 0,06 \\ 654,7 & 0,56\end{array}$

Buğday,

il,Bezelye,Fiğ,Ayçiçeği,Badem,Ceviz,Bağ,Vişne,İğde,

0,06

Bağ,Vişne,

$67,2 \quad 0,06$

Bağ, Vişne,

$424,4 \quad 0,37$

Bağ,Kavun_Karpuz,

$141,5 \quad 0,12$

Bağ

$6396,8 \quad 5,5$

Badem,Ceviz,Bağ,Vişne,Kavun_Karpuz,

$2993,2 \quad 2,58$

Badem,Ceviz,Bağ,Vişne,

$312,5 \quad 0,27$

Badem,Bağ,Vişne,

$16,6 \quad 0,01$

Badem,Bağ,

$1612,1 \quad 1,39$

Arpa,Nohut,Ceviz,Bağ,Vişne, Ĭğde,

$360,1 \quad 0,31$

Arpa,Nohut,Băg,Kavun_Karpuz,

$1422,0 \quad 1,23$

Arpa,Nohut,Bağ,

$10,0 \quad 0,01$

Arpa,Nohut,Badem,Ceviz,Bağ,Vişne,Kavun_Karpuz,

$631,2 \quad 0,54$

Arpa,Bağ,

$164,1 \quad 0,14$

Arpa, Badem, Bağ,

$77,4 \quad 0,07$

Toplam Kuru Tarım

$63837,9 \quad 55,02$

Toplam Alan

116025,3

100,0

Ayrıca İlçe arazileri içerisinde çayır, mera ve orman alanları potansiyel uygunluk durumuna bakıldığında toplam alanın yaklaşık \% 25 karşılık gelen 28788,1 ha çayır-mera alanlarına uygunluk gösterirken, çayır-mera ve orman alanlarına uygunlukları ise 67271,0 ha olup toplam alanın yaklaşık \% 58'ne karşl1ık gelmektedir (Şekil 9).

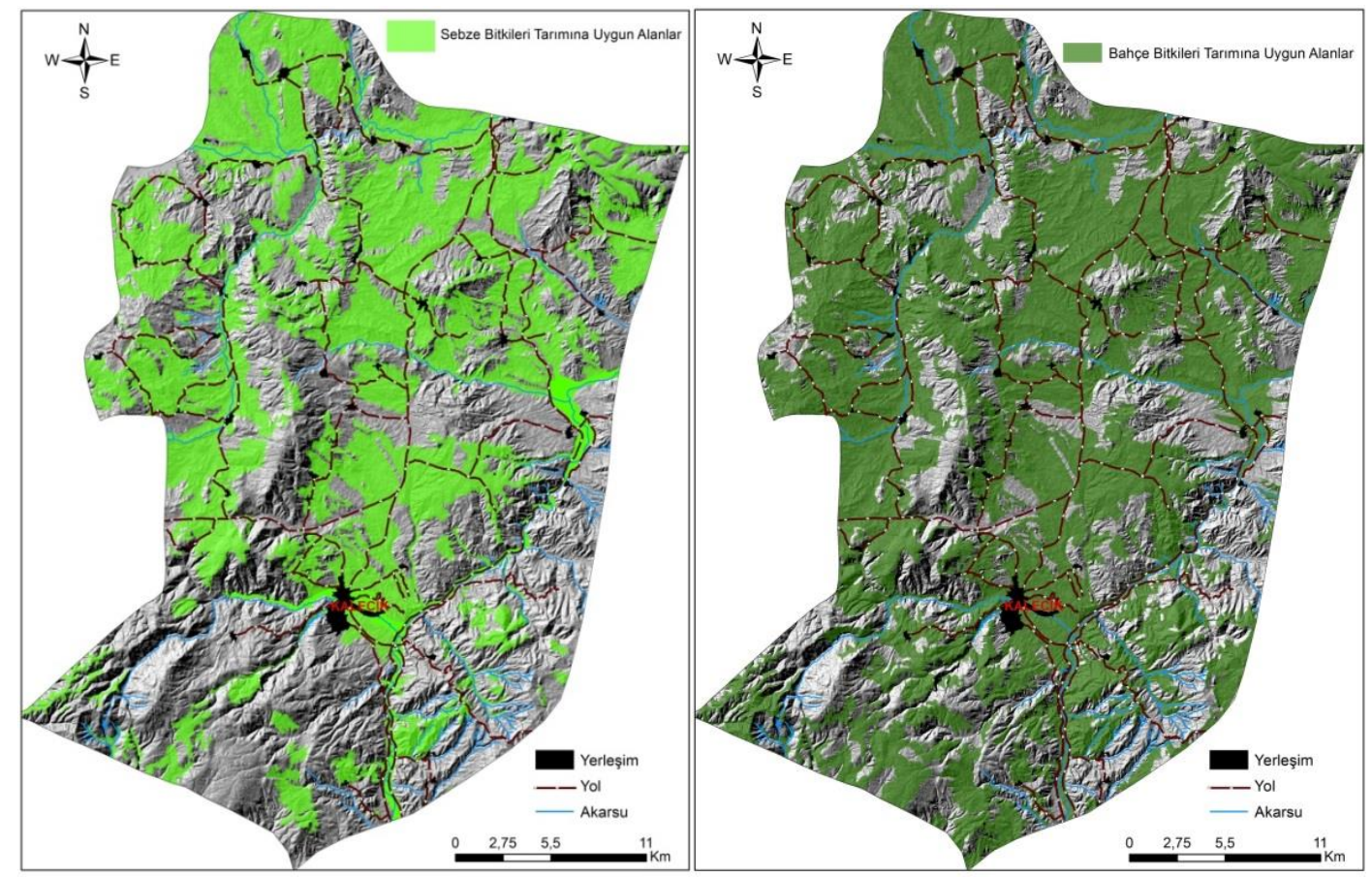



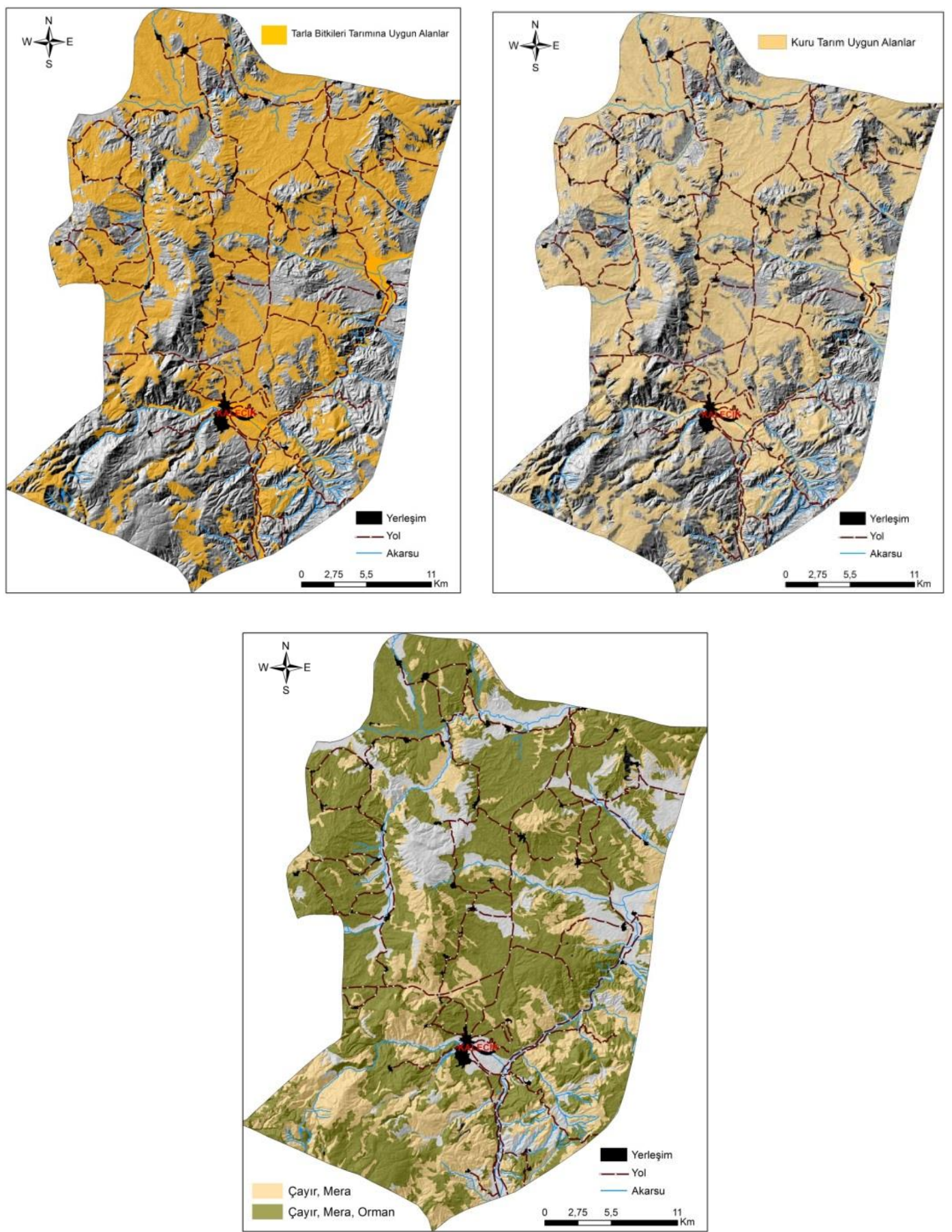

Şekil 9. Sebze, bahçe, tarla bitkileri, kuru tarımsal faaliyete ve çayır, mera ve orman alanlarına uygun alanlar dağılımlarına ait haritalar

\section{Sonuç}

Toprakların güncel sınıflandırma sistemi ile tanımlanması sürdürülebilir arazi ve doğal kaynak yönetimi için bir zorunluluktur. Küresel iklim değişikliği ve bu konuda yapılan öngörüler Türkiye'nin önümüzdeki on yıllarda kurak dönemler geçirecek ülkeler arasında olduğunu göstermektedir. Bu, artan nüfus, sanayileşme baskısı ve diğer coğrafik etmenler düşünüldüğünde gelecek yıllar için Ülkemizin doğal kaynak planlamasını bir an önce yapması gerekliliğini çok açık bir şekilde ortaya koymaktadır.

Doğal kaynakların hızla tüketildiği ülkemizde tarım alanlarının yerleşim ve sanayiye açılması, ulaşım ve yol planlarının olmaması, yanlış arazi kullanımı ve bunların olumsuz etkileri doğal kaynaklarımızın sürdürülebilir yönetiminden çok uzaktır. 
$\mathrm{Bu}$ çalışma ile pilot alan olarak seçilen Kalecik ilçesinde topraklar güncel sınıflandırma sistemi ile sınıflandırılmış ve alan ait arazi kullanım palanları oluşturulmuştur. Böylelikle toprak kaynaklarının verimli kullanımını sağlayan güncel ve yenilenebilir bir toprak bilgi sistemi oluşturulmuştur. Araştırmada tarım yapılması gerekli alanlar, yöreye özgü hangi bitkisel üretim deseninin seçileceği, tarımsal üretime uygun olmayan alanlar ayrı ayrı belirlenmiştir.

Türkiye'nin doğal kaynaklarını koruması, sanayi ve yerleşim alanlarının oluşturulması, doğal kaynaklarla ilgili her türlü tasarrufun doğru ve akılcı bir şekilde yapabilmesi için, ülkenin tümünü kapsayan detaylı toprak etüt çalışmalarına bir an önce başlayıp tamamlaması bir zorunluluktur.

Teşekkür: Bu çalışma Tarımsal Araştırmalar ve Politikalar Genel Müdürlüğü tarafından desteklenmiş olup, katkılarından dolayı teşekkür ederiz.

\section{Kaynaklar}

Abdelrahman, M. A., Natarajan, A., Hegde, R., 2016. Assesment of land suitability and capability by integrating remote sensing and GIS for agriculture in Chamarajanagar District, Karnataka, India. The Egyptian Journal of Remote Sensing and Space Science. 19(1): 125-141.

Aydın, A., Dengiz O., 2020. Sürdürülebilir arazi yönetimi için arazi değerlendirmesi çalışması; Samsun- Kavak İlçesinde örnek bir çalı̧̧ma. Bursa Uludağ Üniversitesi Ziraat Fakültesi Dergisi. 34(1): 1-17.

Cinemre, H.A ve Dengiz, O., 2010. Arazi kullanım planlaması. Ondokuz Mayıs Üniversitesi Ziraat Fakültesi Ders Kitabi No: 64, Samsun.

Demirel, B. Ç., Şenol, S., 2019. Hızlı büyüme potansyeline sahip yerleşim alanlarının detaylı toprak etütleri ve arazi değerlendirmeleri: Mustafalar Köyü örneği, Adana. Yüzüncü Yıl Üniversitesi Tarım Bilimleri Dergisi. 29(4): 711-721.

Dengiz, O., Bayramin, I., Yuksel, M., 2003. Geographic information system and remote sensing based land evaluation of Beypazari area soils by ILSEN model. Turkish Journal of Agriculture and Forestry. 27(3): $145-153$.

Dengiz, O., Özdemir, N., Öztürk, E., Yakupoğlu, T., 2009. Doğu Karadeniz Bölgesi findık arazilerinin tarımsal kullanıma uygunluk sınıflarının belirlenmesi, pilot çalışma; Ünye- Tekkiraz Beldesi. Anadolu Tarım Bilim. Derg. 24(3): 174-183.

FAO., 1976. A Framevork for land evaluation, Soils bulletin: 32, Food and Agriculture Organization of the United Nations, Rome, Italy.

FAO., 1977. A Framework for land evaluation. Pub.22. Wageningen, The Netherlands.

FAO., 1989. Guidelines for land use planning. Interdepermantal working group on land planning, FAO, Rome.

Kınalı, T., Erol, U. E., Kaya, L. G., 2020. Isparta- İslamköy örneğinde arazi toplulaştırma çalışmalarının mekansal olarak değerlendirilmesi. Mehmet Akif Ersoy Ünversitesi Fen Bilimleri Enstitüsü Dergisi. 11(2): 150-163.

Smyth, A. and Dumanski, J., 1993. FESLM: An International framework for evaluating sustainable land management, FAO Rome, p.85.

Soil Survey Staff., 1999. Soil Taxonomy. A Basic of soil classification for making and interpreting soil survey. U.S.D.A Handbook No: 436, Washington D.C.

Şenol, S. ve Tekeş, Y., 1995. Arazi değerlendirme ve arazi kullanım planlaması amacıyla geliştirilmiş bir bilgisayar modeli. I. Akalan Toprak ve Çevre Sempozyumu. Ankara.

Şenol, S., 1983. Arazi toplulaştırma çalışmalarında kullanılabilir niceliksel yeni bir arazi değerlendirme yönteminin geliştirilmesi üzerine araştırmalar. Ç.Ü. Fen Bilimleri Enstitüsü Toprak ABD Doktora Tezi (Basılmamış) Adana.

Turan, M.A., Katkat, A. V., Özsoy, G., Taban, S., 2010. Bursa İli alüviyal tarım topraklarının verimlilik durumları ve potansiyel beslenme sorunlarının belirlenmesi. U. Ü. Ziraat Fakültesi Dergisi. 24(1): 115130. 